OPEN ACCESS

Edited by:

Mark S. Cragg,

University of Southampton,

United Kingdom

Reviewed by:

Alexander Rölle,

Nationales Centrum für

Tumorerkrankungen (NCT), Germany

Ahmed Lasfar,

Rutgers University, The State

University of New Jersey,

United States

*Correspondence:

Adam W. Barb

abarb@iastate.edu

Specialty section:

This article was submitted to

Molecular Innate Immunity,

a section of the journal

Frontiers in Immunology

Received: 30 November 2018

Accepted: 25 January 2019

Published: 14 February 2019

Citation:

Patel KR, Roberts JT and Barb AW

(2019) Multiple Variables at the

Leukocyte Cell Surface Impact Fc $\gamma$

Receptor-Dependent Mechanisms.

Front. Immunol. 10:223.

doi: 10.3389/fimmu.2019.00223

\section{Multiple Variables at the Leukocyte Cell Surface Impact Fc $\gamma$ Receptor-Dependent Mechanisms}

\author{
Kashyap R. Patel, Jacob T. Roberts and Adam W. Barb* \\ Roy J. Carver Department of Biochemistry, Biophysics, and Molecular Biology, lowa State University, Ames, IA, United States
}

Fc $\gamma$ receptors $(\mathrm{Fc} \gamma \mathrm{R})$ expressed on the surface of human leukocytes bind clusters of immunoglobulin $\mathrm{G}(\mathrm{lgG})$ to induce a variety of responses. Many therapeutic antibodies and vaccine-elicited antibodies prevent or treat infectious diseases, cancers and autoimmune disorders by binding FcyRs, thus there is a need to fully define the variables that impact antibody-induced mechanisms to properly evaluate candidate therapies and design new intervention strategies. A multitude of factors influence the lgG-Fc $\gamma$ R interaction; one well-described factor is the differential affinity of the six distinct Fc $\gamma$ Rs for the four human IgG subclasses. However, there are several other recently described factors that may prove more relevant for disease treatment. This review covers recent reports of several aspects found at the leukocyte membrane or outside the cell that contribute to the cell-based response to antibody-coated targets. One major focus is recent reports covering post-translational modification of the FcyRs, including asparagine-linked glycosylation. This review also covers the organization of Fc $\gamma R$ s at the cell surface, and properties of the immune complex. Recent technical advances provide high-resolution measurements of these often-overlooked variables in leukocyte function and immune system activation.

Keywords: antibody, IgG, N-glycosylation, post-translation modification, ADCC-antibody dependent cellular cytotoxicity, immune complex, ADCP-antibody dependent cellular phagocytosis

\section{INTRODUCTION: THE IMPORTANCE OF MODULATING THE Fc-Fc $\gamma R$ INTERACTION}

Immunoglobulin $\mathrm{G}(\mathrm{IgG})$ is the most thoroughly studied and well characterized molecule of the humoral immune response. IgG activates the immune system through cell-bound Fc $\gamma$ Receptors (Fc $\gamma$ Rs; Figure 1). The IgG fragment antigen-binding (Fab) domains confer specificity and affinity toward an antigen while the distinct hinge and fragment crystallizable $(\mathrm{Fc})$ domain of the four IgG subclasses (IgG1-4) provide the structural basis for specificity and affinity to bind Fc $\gamma$ Rs (1). The six structurally distinct members of the classical human Fc $\gamma$ Rs (Fc $\gamma R I$ or CD64, Fc $\gamma$ RIIa/CD32a, Fc $\gamma$ RIIb/CD32b, Fc $\gamma$ RIIc/CD32c, Fc $\gamma$ RIIIa/CD16a, and Fc $\gamma$ RIIIb/CD16b) are expressed on leukocytes of both the myeloid and lymphoid lineage (Figure 2). This group of proteins can be divided into two types: activating receptors (CD64, CD32a, CD32c, CD16a, and CD16b) that lead to cell activation through immunoreceptor tyrosine-based activation motifs (ITAM) on cytosolic tails or on co-receptor molecules, and an inhibitory receptor (CD32b) that signals through immunoreceptor tyrosine-based inhibitory motifs (ITIM) (2-4). Only CD32s contain ITAM or ITIM domains, and the other receptors must associate with an ITAM-containing 


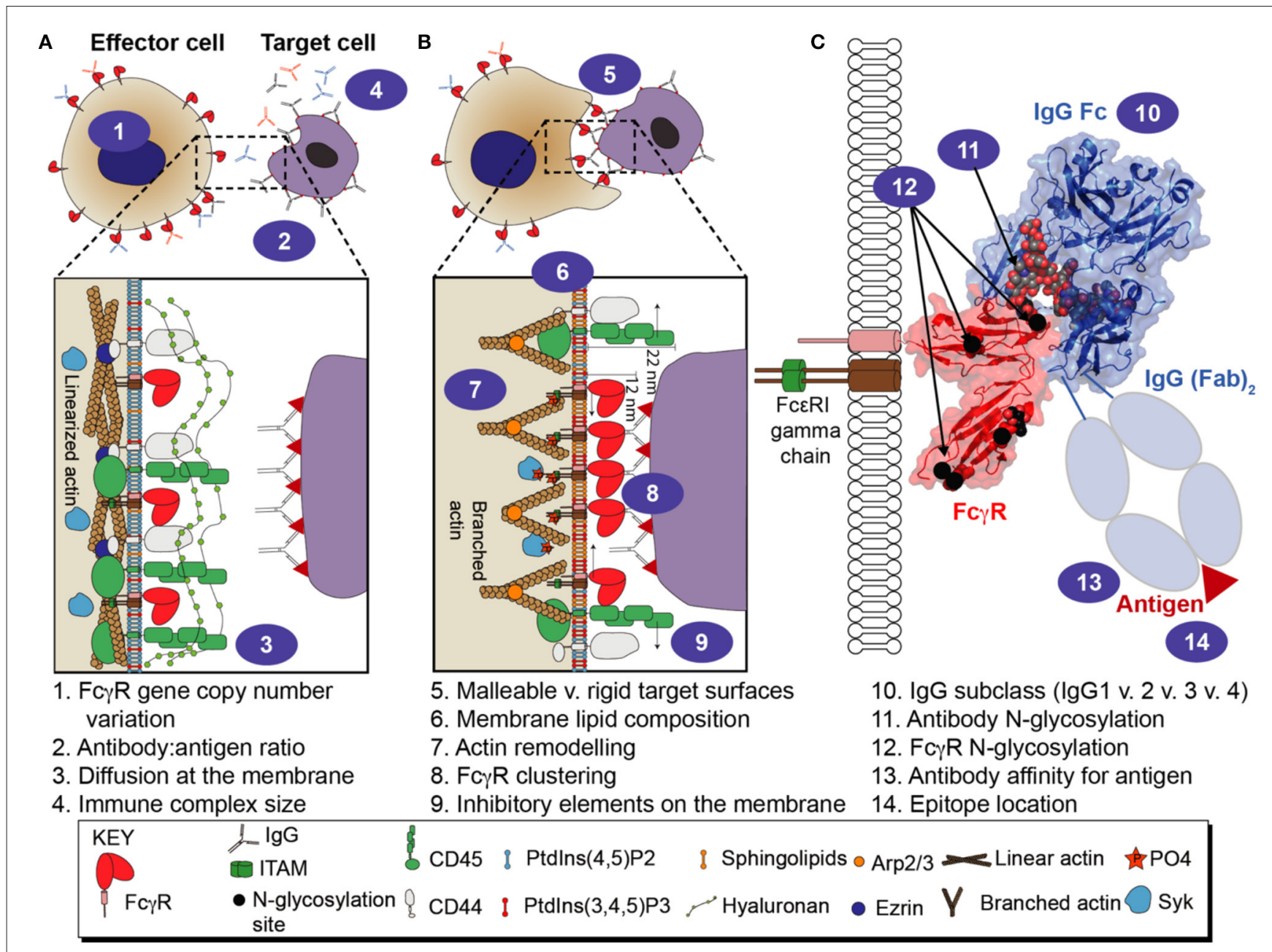

FIGURE 1 | Multiple variables affect Fc $\gamma R$-mediated immune function. (A) cellular variables influencing Fc $\gamma R$ activity that are present before the effector cell engages a target cell. (B) cellular variables influencing Fc $\gamma$ R-mediated activity while the effector cell is engaged with a target cell. (C) molecular variables associated with the Fc $\gamma$ Rs, antibody, and antigen.

adaptor protein (FceRI $\gamma$ chain or CD3 $\zeta$ chain) $(3,5)$ (Figure 2). In either situation, the ratio of activating to inhibiting signals determines the outcome of an immune response (6).

Receptor clustering is essential for $\mathrm{Fc} \gamma \mathrm{R}$ signaling. Circulating IgG coats an antigen to form an oligomeric complex, positioning the Fc portions of the IgG molecules away from the target surface and exposed to interact with Fc $\gamma$ Rs. The antibody-coated target is also referred to as an immune complex. The multiple IgG molecules of the immune complex provide an opportunity for multivalent interactions with Fc $\gamma$ R-expressing leukocytes and must compete with non-complexed serum antibodies occupying the Fc $\gamma$ Rs that will, in turn, cluster Fc $\gamma$ Rs on the cell surface $(7,8)$. Depending on the receptors engaged, the clustering of the extracellular domains triggers phosphorylation of tyrosine in the ITAMs or ITIMs, which subsequently recruits signaling molecules that promote a cellular response (9). The types of Fc $\gamma$ R-mediated effector cell responses are diverse and include, but are not limited to, antibody-dependent cellular cytotoxicity
(ADCC), antibody-dependent cellular phagocytosis (ADCP), release of cytokines and antigen uptake for presentation (10-14). $\mathrm{Fc} \gamma$ Rs are critical for maintaining immune system homeostasis as well as preventing pathogenic infections and they play a major role in inflammatory diseases and autoimmune disorders $(9,13$, 15-17). The combination of distinct antagonistic and synergistic factors contribute to a considerable functional diversity within this group of antibody receptors. Here we will discuss multiple factors which influence the antibody: $\mathrm{Fc} \gamma \mathrm{R}$ interaction and modify the immune response (Figure 1).

\section{RECEPTOR PRESENTATION AT THE CELL SURFACE}

Fc $\gamma$ Rs are predominately expressed on cells originating from hematopoietic progenitor stem cells including dendritic cells, neutrophils, basophils, eosinophils, macrophages, monocytes, 


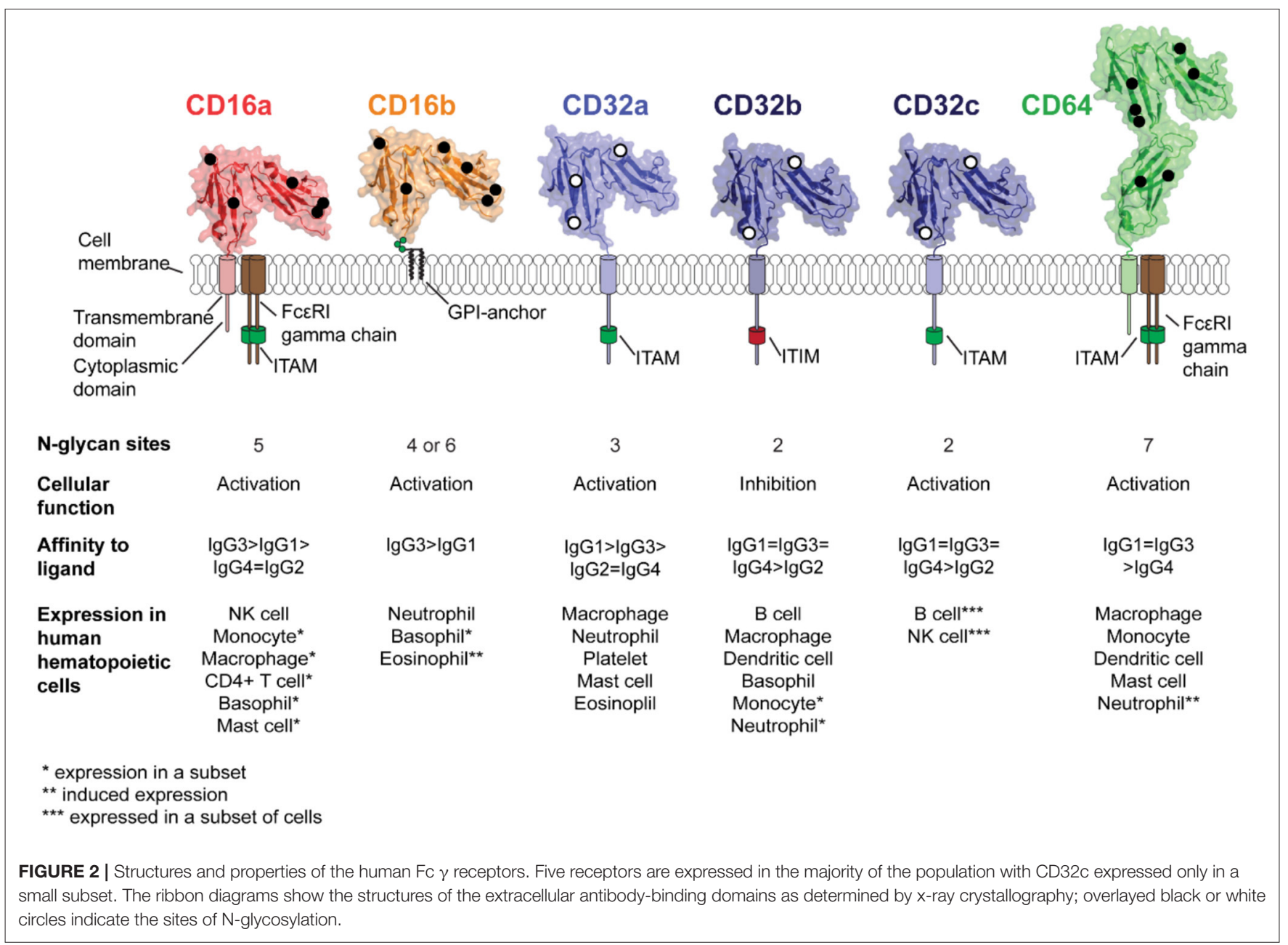

mast cells, NK cells, B cells, a subset of T cells, and platelets as well as non-hematopoietic cell types such as syncytiotrophoblasts at various levels (18-20). Fc $\gamma \mathrm{R}$ expression varies depending on cell lineage; not surprisingly gene copy number is also implicated in disease. These factors can greatly influence the dynamic ability of the immune system to respond to the diverse repertoire of foreign invaders. Thus, variable surface expression by different immune cell types influences how the immune system responds to a foreign invader. This section will cover the cellular expression of Fc $\gamma$ Rs and immune modulation of expression through downregulation and induction.

Five activating Fc $\gamma$ Rs are expressed in humans (Figure 2). The highest affinity, CD64, is expressed on monocytes, dendritic cells and macrophages (11), mast cells (21), and neutrophils following IFN- $\gamma$ exposure $(22,23)$. The low affinity CD32a is expressed on mast cells, neutrophils, macrophages, eosinophils, and platelets (24). CD32c is expressed by $7-15 \%$ of individuals on NK cells and $\mathrm{B}$ cells and results from a gene mutation (4). The high/moderate affinity CD16a is expressed predominantly on NK cells, a subset of monocytes, mast cells, basophils, macrophages and is inducible in CD4+ T-cells $(25,26)$. The low/moderate affinity CD16b is found only in humans and expressed predominantly on neutrophils (27), a subset of basophils (28) and has inducible expression on eosinophils $(29,30)$. CD32b is the sole inhibitory receptor and is expressed on basophils, B cells, macrophages, dendritic cells, a subset of monocytes and neutrophils (24). Interestingly, CD32b is also expressed in non-hematopoeitic cells, including the endothelium of various organs (31).

\section{Variability in Receptor Amount}

Gene duplications in individuals lead to copy number variation (CNV) of some Fc $\gamma$ Rs in the population. Surprisingly, only CD16a, CD16b, and CD32c of the Fc $\gamma$ Rs exhibited CNV in a sample population of 600 subjects (32). CNVs have been correlated to autoimmune disorders as well as variations in surface expression levels. CNV of CD16b is correlated to surface expression on neutrophils and implicated in SLE susceptibility $(33,34)$, as well as other autoimmune disorders $(35,36)$. Furthermore, CD16a CNV appears to be functionally significant since increased surface expression positively correlated with increasing CD16a gene number (ranging from one to three copies) $(32,35)$. A CD16a indel has been shown to increase surface expression as well (37). 
Fc $\gamma$ R amount at the cell surface varies by cell type and receptor identity (Figure 2). On neutrophils, there are an estimated 100,000-300,000 surface exposed CD16b molecules and 10,00040,000 CD32a molecules $(38,39)$. The predominant monocyte subtype at roughly $80 \%$ of the pool, "classical" monocytes, does not express CD16a. "Non-classical" monocytes express CD16a at a level of roughly $10,000 \mathrm{CD} 16 \mathrm{a}$ molecules per cell but upon differentiation into macrophages express 40,000 CD16a molecules per cell while CD32 remained the same at $\sim 10,000$ molecules per cell (40). Another study found macrophages express 5-10 fold higher CD64, CD32a, and CD32b while CD16a expression was comparable to non-classical monocytes. M2c macrophages expressed overall higher levels of Fc $\gamma$ Rs than M1 macrophages with the following order of expression: CD32a, CD32b > CD64 > CD16a (41). A high number of CD16a molecules are expressed on CD16+ NK cells $(100,000-$ 250,000) (42).

Expression levels also vary based on the cell status. Following activation, innate immune cells can induce expression of Fc $\gamma$ Rs $(23,25,29,30,35)$. There is also evidence of receptor downregulation upon activation. Downregulation mechanisms include both decreases in expression as well as shedding Fc $\gamma \mathrm{R}$ from the cell surface following metalloproteinase cleavage. CD32a is shed from Langerhans cells and also expressed as a soluble form (43). CD32b is shed upon activation of B-cells (44). CD16a and CD16b are likewise shed upon activation of NK cells and neutrophils at a known cleavage site by the metalloprotease ADAM17 (45-48). Intriguingly, sCD16b is relatively abundant in serum ( $~ 5 \mathrm{nM})(49)$ and levels vary based on the immune state of the individual (50). Surprisingly, CD64 is the only human Fc $\gamma$ R in which a soluble, serum-borne form has not been reported. This may be explained by the presence of a third extracellular CD64 domain in place of the cleavage site found in CD32s and CD16s (Figure 2).

Soluble Fc $\gamma \mathrm{R}$ forms modulate immune responses. Soluble CD16b binds myeloid cells, NK cells, subsets of T cells, B cells, and monocytes through complement receptor 3 (CR3 or Mac- 1 or $\alpha \mathrm{M} \beta 2$, comprised of CD11b/CD18) and complement receptor 4 (CR4 or $\alpha \mathrm{x} \beta 2$, comprised of CD11c/CD18). These interactions cause the release of IL6 and IL8 by monocytes and indicate a potential role for soluble CD16b in inflammation (51). Shedding of CD16a from NK cells allows disengagement of the immune synapse from the target cell and the subsequent ability to kill again. One study demonstrated that repeated engagement by CD16a depleted perforin, however, shedding of CD16a allowed perforin replenishment upon subsequent activation by another activating receptor, Natural killer group 2 member D (NKG2D), which recognizes ligands not normally expressed on healthy tissue (52). Thus, it appears that the act of shedding of CD16 can allow disengagement of the foreign particle which would be crucial for the immune cell's survival and preservation of potential future cytolytic activity. Though shed receptors are proinflammatory and recruit immune cells as discussed above, a complete picture of the mechanisms of regulating surface expression upon immune activation is not currently available.

\section{Receptor Clustering at the Membrane Is Required for Effector Function}

The correct presentation of Fc $\gamma$ Rs on the cell membrane is essential for proper immune cell function. ADCC can destroy virally infected cells and cancer cells, and is thus a target for monoclonal antibody (mAb) therapies (53). ADCP is also an important mechanism in $\mathrm{mAb}$ therapy targeting malignant cells (14). ADCC and ADCP are dependent on the ability of low to moderate affinity Fc $\gamma$ Rs to cluster on fluid plasma membranes for activation to occur (54) (Figure 1). Equally important is the regulation of these receptors when no activation signal is present.

Proper activation of $\mathrm{Fc} \gamma \mathrm{Rs}$ following $\mathrm{Fc}$ engagement by macrophages requires clustering of $F c \gamma$ Rs and the displacement of inhibitory receptors. In one study utilizing murine RAW 264.7 cells, segregation of CD45, a phosphatase responsible for dephosphorylating ITAMs, is dependent on antigen distance from the target membrane (55) (Figure 1). It appears that if the antibody is $>10 \mathrm{~nm}$ from the target surface, there is a substantially impaired ADCP response. This phenomenon is due to the location of the epitope; epitopes closer to the surface exclude the inhibitory CD 45 molecule (which stands $\sim 22 \mathrm{~nm}$ tall vs. Fc $\gamma$ R-IgG complex $=11.5 \mathrm{~nm}$ ) from the immune synapse. Interestingly, a follow-up study that focused on FDA-approved $\mathrm{mAbs}$ found the targets were small surface proteins $(<10 \mathrm{~nm}$ in height) suggesting there may be a requirement for $\mathrm{mAb}$ epitopes to be located close to the surface for therapeutic efficacy. CD45 was also excluded from the immune synapse in activated human T cells (56). Another study concerning inhibitory module segregation on human macrophages demonstrates CD64, but not $\mathrm{CD} 32 \mathrm{a}$, and inhibitory signal regulating protein $\alpha(\operatorname{SIRP} \alpha)$, in conjunction with CD47 (a receptor that inhibits macrophage phagocytosis), are clustered on quiescent cells but upon activation segregate in a process regulated by spleen tyrosine kinase (SYK)-dependent actin cytoskeleton reorganization (57). Recently, Fc $\gamma \mathrm{R}$ diffusion has been shown to be inhibited by the CD44 transmembrane protein which is immobilized by linearized actin filaments via ezrin/radixen/moesin (ERM) and binds hyaluronan in the glycocalyx (58). This study used primary human macrophages as well as murine cell lines and murine models, utilizing single particle tracking found CD44 and hyaluronan decreased the diffusion rate of $F c \gamma R s$, while also sterically blocking the binding of FcyRs to immune complexes (Figure 1).

Receptor clustering overwhelms constitutive inhibition as described previously, allowing phosphorylation of the ITAM. ITAMs are phosphorylated via SYK, Src family kinase (SFKs) or $\zeta$-chain-associated protein kinase 70 (ZAP-70) for downstream activation of phosphoinositide-3-kinase (PI3K), NF- $\kappa$ B, extracellular signal regulated kinase (ERK), phosphatidyl inositol 4-phosphate 5-kinase $\gamma$ (PIP5K $\gamma$ ), GTPases and other SRC-family kinases $(53,54,59,60)$. Along with Fc $\gamma$ R clustering, actin polymerization and depolymerization is equally important for phagocytosis in RAW 264.7 macrophages by creating lammellipodium/pseudopods. These protrusions are controlled by Rac GTPase and lipid composition (54, 59) (Figure 1). Clustering has also been observed on the plasma membrane 
of murine derived macrophages using total internal reflection microscopy (TIRF) of a lipid bilayer supporting IgG (61). The $\mathrm{Fc} \gamma \mathrm{R}$ microcluster appears on the macrophage pseudopod edge and is subsequently transported to a synapse-like structure thereby recruiting SYK and production of PtdIns(3-5)P3 coordinated with lamellar actin polymerization. Another study on quiescent human macrophages found lateral diffusion of Fc $\gamma$ Rs is regulated by tonic activity of SYK causing actin cytoskeleton organization to increase the likelihood of Fc $\gamma$ Rs to be pre-clustered upon finding a pathogen (62). This study further described differential Fc $\gamma$ R mobility upon activation. Fc $\gamma$ Rs at the periphery of the actin-rich pseudopod were more mobile than those already immobilized by binding of IgG-rich regions. The authors explained that this mobility difference is controlled by SYK-mediated regulation of the actin-cytoskeleton which would increase the likelihood of Fc $\gamma$ Rs to engage more IgG molecules at the leading edge of the lamellipodium/pseudopod and not waste time diffusing into already IgG-dependent, Fc $\gamma$ R-immobilized, actin-rich rich regions of plasma membrane. Mobility of Fc $\gamma$ Rs was described earlier to be decreased at the trailing end of polarized macrophages by CD44 that was bound to linear actin and connected to hyaluronan (58). It was also found in this study that on the leading edge of polarized macrophages, the side that encounters opsonized material, Arp2/3-driven actin branching predominates, initiated by phosphotidlyinosotide (3-5)-trisphosphate production, and increased Fc $\gamma \mathrm{R}$ mobility allowing for more efficient clustering at the immune synapse. When Arp2/3-driven actin branching predominates, it was found CD44 is more mobile allowing greater $\mathrm{Fc} \gamma \mathrm{R}$ mobility (Figure 1).

In the human NK92 cell line, transduced to express CD16a, a study showed $\beta 2$ integrins mediate the dynamics of $\mathrm{Fc} \gamma \mathrm{R}$ receptor microclusters in a protein-tyrosine kinase 2 (Pyk2)dependent manner, controlling the rate of target cell destruction by ADCC (63). $\beta 2$ integrins bind ICAM-1 on the target cell allowing adhesion and signal transduction through Pyk2 for actin remodeling and the subsequent enhancement of $\mathrm{Fc} \gamma \mathrm{R}$ mobility. Furthermore, sites of granule release are surrounded by clusters of CD16a and release points are devoid of actin. Human NK cell lytic granules also converge at the surface in a dynein and integrin-signal dependent manner which aids spatial targeting of the weaponized molecules to limit off-target damage (64). Surprisingly, CD16a is essential for ADCC of human CD16+ monocytes and upon CD16a engagement, $\beta 2$ integrins are activated along with $\mathrm{TNF} \alpha$ secretion thereby indicating that non-classical monocytes (CD16+) are the sole monocyte class capable of ADCC (65).

During the early stages of phagocytosis by RAW 264.7 cells, direct contact between Fc $\gamma$ Rs and IgG is increased by greater IgG density on particles, and increased IgG density results in an increased level of early signals. However, late stage signals are "all or nothing," not concentration dependent, and regulated by PI3K concentration in the phagocytic membranes (66). In this study, low IgG density decreased the amount of opsonized particles but not the rate of phagosome formation and low IgG density particles that did result in phagocytosis recruited the same amounts of late stage signaling molecules (PIP3, Protein kinase $\mathrm{C} \varepsilon$ type, $\mathrm{p} 85$ subunit) and actin. Overall it appears that $\mathrm{Fc} \gamma \mathrm{Rs}$ control the initial binding process essential for scanning the foreign particle and initial activation by binding IgG and later stages of commitment to destruction of the particle are controlled by both IgG density and membrane lipid composition.

On murine and human macrophages, receptor clustering upon activation is consistent with a change in the heterogeneity of the membrane lipid composition to a highly ordered phagosomal membrane that is heavily enriched in sphingolipids and ceramide but lacking cholesterol (67) (Figure 1). The authors state that lipid remodeling mediates F-actin remodeling and the biophysical characteristics of the phagosomal membrane are essential for phagocytosis. On human B cells, a polymorphism of the inhibitory receptor CD32b (Ile232Thr) located in the middle of the transmembrane domain, is described to decrease inhibitory function (68). This mutation was shown to result in aberrant localization to a sphingolipid and cholesterol rich region in contrast to the Ile232 wild-type. Aberrant localization is not surprising considering the introduction of a polar residue into the transmembrane domain (69). Furthermore, the ability of $\mathrm{CD} 32 \mathrm{~b}$ to inhibit $\mathrm{B}$ cell receptor (BCR)-mediated PIP3 production, AKT, phospholipase $\mathrm{C}-\gamma-2$ (PLC $\gamma 2)$ activation and calcium mobilization was impaired in cells expressing the CD32b Thr232 allotype as compared to Ile232. The authors indicate the $\mathrm{Fc} \gamma \mathrm{R}$ locus was associated with SLE and this polymorphism may promote disease. Thus, it appears lipid composition is important for Fc $\gamma$ R-mediated mechanisms.

The unique construction of CD16b indicates the potential for a different activation mechanism for neutrophils. Neutrophils predominantly express CD16b with 10-fold less CD32a. CD32a signal transduction is well described and thought to be the canonical Fc $\gamma \mathrm{R}$ signal transduction via phosphorylation of ITAMs and subsequent SYK recruitment (70). However, CD16b contains a GPI anchor and does not have a polypeptide transmembrane domain nor is it known to associate with a signaling coreceptor, therefore, it is unclear how CD16b promotes signaling in neutrophils (Figure 2). CD16b plays a role in the initial binding of immune complexes in concert with $\beta 2$ integrins (71). Currently there are conflicting studies suggesting that CD16b can transduce a signal on its own $(70,72,73)$, or it transduces a signal by acting with CD32a (74). A recent study found CD16b cross-linking increased IL10 and TNF $\alpha$ expression, phosphorylated SHP-2 in a lipid-raft mediated manner and inhibited apoptosis in neutrophils. Lipid composition certainly may be an important part of CD16b signal transduction in mechanisms similar to those discussed previously for macrophage phagocytosis and CD32b on B-cells, however the role of lipids in neutrophil activation is not understood (75-81). Interestingly proteinase 3 (PR3), CD16b, cytochrome b558, and NADPH oxidase co-immunoprecipitate on lipid rafts and PR3 and CD16b colocalize in confocal imaging suggesting these may interact in a lipid raft (75). Other findings suggest CD16b signals in conjunction with CR3 via lectin-like interactions (82), leading to neutrophil respiratory bursts (72). The function of GPI-linked $\mathrm{CD} 16 \mathrm{~b}$ remains undefined despite the high abundance of CD16b in the body and critical roles in mAb therapies (83). 


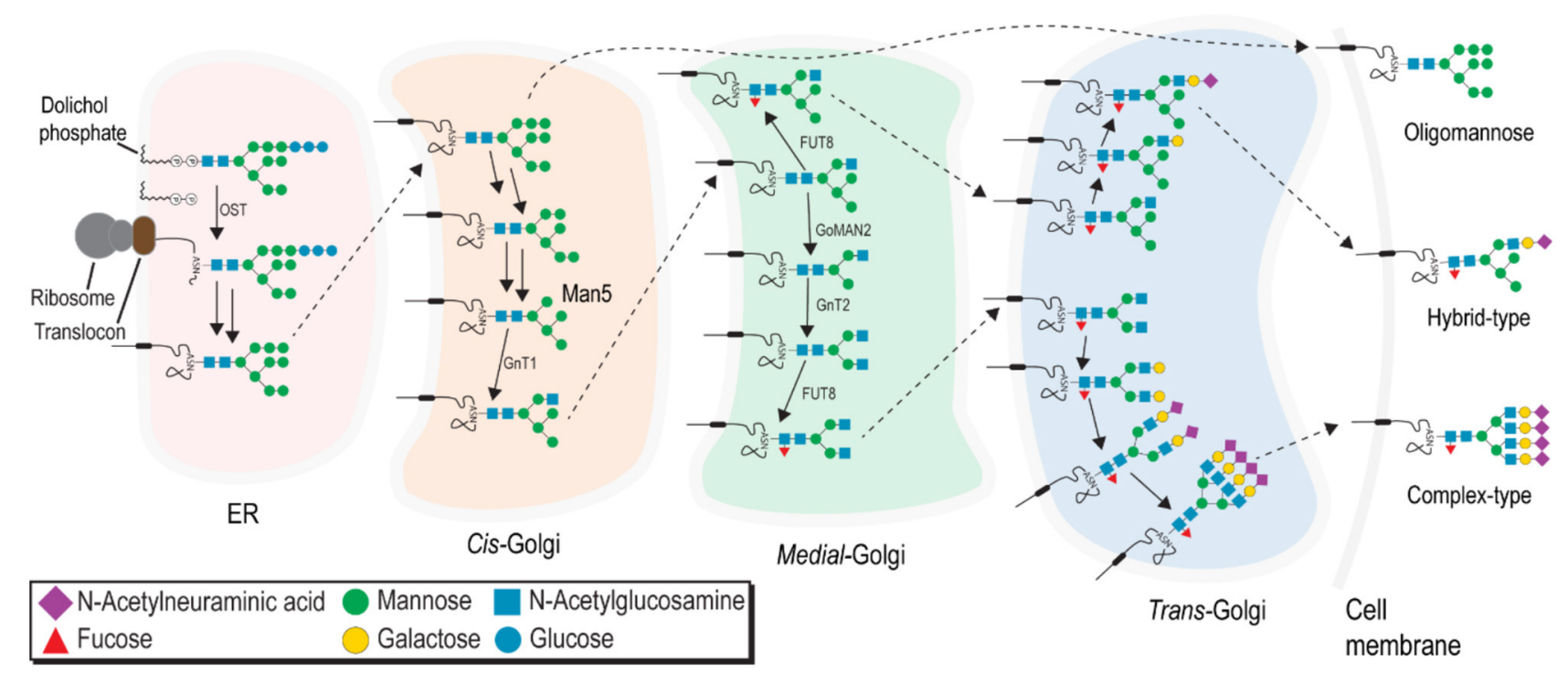

FIGURE 3 | N-glycans are processed in the ER and Golgi to produce three major classes: minimally processed oligomannose-type N-glycans, fully processed complex-type N-glycans, and hybrid-type N-glycans with an intermediate level of processing.

\section{The Type of Fc $\gamma R$ Membrane Anchor Impacts Activation}

There are clear differences between the signaling and antibodybinding affinity of soluble and membrane-anchored $\mathrm{F} \gamma \mathrm{R}$ forms. However, less is known about the effects of the specific $F c \gamma R$ membrane anchors on affinity and cell activation. All Fc $\gamma$ Rs are localized to the membrane by a transmembrane polypeptide moiety or a glycosylphosphatidylinositol (GPI) moiety (CD16b only) (Figure 2). A micropipette adhesion assay demonstrated CD16a attached to microspheres via a GPI anchor bound roughly 5 -fold tighter to IgG1-coated red blood cells (RBCs) than CD16a tethered by a transmembrane domain $(84,85)$. Interestingly, it also appears IgG1-coated spheres treated with phosphoinositide phospholipase C (PIPLC) to remove the diacylglycerol moiety bound to GPI-linked CD16a with 12-fold less affinity. These authors observed a 60 -fold decrease when the GPI-anchor was completely removed. A CD16b-GPI construct showed 2-fold decrease of affinity upon PIPLC treatment and an 11-fold decrease following removal of the GPI-anchor. The authors hypothesized that enhancement of binding affinity associated with the GPI anchor may be due to an allosteric effect on CD16, changing the structure to bind IgG more effectively; such an allosteric mechanism was observed with other GPI-anchored proteins (80). Further studies will be required to fully elucidate how the GPI-anchor affects CD16b and how specific aspects of the membrane anchor confers distinct properties in vivo.

\section{POST-TRANSLATIONAL MODIFICATION OF THE ANTIBODY AND RECEPTOR}

Asparagine-linked (N-) glycosylation is one of the most common protein modifications performed by the eukaryotic cell and is a substantial modification of all Fc $\gamma$ Rs [Figure 2; for a thorough review of $\mathrm{N}$-glycan processing, see (86)].It is important to note, however, the resulting glycans processed in the ER and Golgi can be grouped into three distinct forms: (1) minimally-processed oligomannose type $\mathrm{N}$-glycans, (2) intermediate processed hybrid-type $\mathrm{N}$-glycans with processing on one of the two core mannose branches, and (3) highlyprocessed complex-type $\mathrm{N}$-glycans with extensively modified branches (Figure 3).

Several variables introduce a significant degree of heterogeneity into the $\mathrm{N}$-glycan present at any single site on a glycoprotein, ranging from substrate availability, protein anchor type, to accessibility of $\mathrm{N}$-glycan site, potentially creating a vast diversity of protein forms and functions (87-90). This heterogeneity also renders glycoproteins challenging targets for in vitro studies to characterize structure. Minimally-processed hybrid and oligomannose type $\mathrm{N}$-glycans are not expected at the cell surface because these forms harbor terminal mannose residues that may bind to the mannose receptor and elicit an immune response $(91,92)$. Though many previous glycomics studies report high levels of oligomannose $\mathrm{N}$-glycans recovered from primary cells, the abundance of these under-processed forms is likely due to cell lysis and recovery of unprocessed glycans from the ER. If under-processed forms are present on the cell surface, these must be protected from binding to the mannose receptor. Therefore, highly processed complex-type $\mathrm{N}$-glycans are expected as the predominant species at the cell surface.

The functional impact of N-glycosylation at the conserved asparagine 297 residues in IgG1 is well established. IgG1 glycosylation at Asn-297 is essential for the IgG-Fc $\gamma$ R interaction (93). The N-glycosylation profile of serum IgG changes due to multiple factors, including age, gender, infection, pregnancy, and disease (94-97). The variation in IgG1 Fc glycoforms is known to change antibody affinity toward the 
Fc $\gamma$ Rs (98), and this fact has also been leveraged to develop glycoengineered $\mathrm{mAbs}$ and anti-inflammatory glycoforms of intravenous immunoglobulin (IVIG) $(99,100)$. The wealth of knowledge regarding $\operatorname{IgG}$ glycoforms is due in large part to protein abundance and ease of obtaining samples. However, little is known about the glycosylation of Fc $\gamma$ Rs on immune cells.

Fc $\gamma$ Rs are heavily glycosylated molecules, containing two to seven N-glycans (Figure 2). The extent of Fc $\gamma \mathrm{R}$ modification was evident as early as 1988 as certain Fc $\gamma$ Rs from native tissue migrated much slower in SDS-PAGE gels than expected based on the polypeptide mass alone. Furthermore, the migration rate increased after treatment to specifically remove N-glycans (101, 102). There is a prominent gap in knowledge about the impact of Fc $\gamma$ R N-glycosylation on immune function largely due to limited studies of the native $F c \gamma$ Rs purified from primary leukocytes. However, it is known that CD16a expressed by NK cells had a distinct $\mathrm{N}$-glycosylation profile when compared CD16a expressed by cultured monocytes, though this determination was made using lectin binding (103) and surface CD16a on the NK cell and monocyte displayed differential antibody-binding affinity that was attributed to differences in cell-specific CD16a N-glycosylation (104).

Even though native glycoforms of all Fc $\gamma$ Rs are not known, the effect of $\mathrm{N}$-glycosylation on binding affinity has been well characterized in vitro using protein expressed with mammalian cells. Aglycosylated, recombinant, soluble (s)Fc $\gamma$ Rs bind IgG1 $\mathrm{Fc}$ at different affinities than glycosylated forms, thus the IgG$\mathrm{Fc} \gamma \mathrm{R}$ interaction is sensitive to receptor N-glycosylation (105107). Recent studies reported substantial differences in affinity for $s F c \gamma$ Rs expressed in recombinant systems (106, 108-110), $\mathrm{N}$-glycosylation profiles of NK cell CD16a and soluble CD16b from serum revealed surprising heterogeneity and substantial differences from recombinantly-expressed protein $(109,111)$.

\section{Specific CD16a Glycoforms Bind Antibody With High Affinity Comparable to CD64}

The analysis of $\mathrm{N}$-glycan composition from $\mathrm{Fc} \gamma \mathrm{Rs}$ provides a characteristic profile of a protein (112). Glycomics analysis of CD16a on circulating NK cells from three healthy donors revealed a surprising abundance of under-processed forms ( $\sim 45 \%$ hybrid and oligomannose-type N-glycans). CD16a is $\mathrm{N}$-glycosylated at five sites (Figure 2). The remainder of the $\mathrm{N}$-glycans were primarily complex type, biantennary $\mathrm{N}$ glycan structures with a high degree of sialylation $(78 \%)$ and fucosylation (89\%) (109). The under-processed forms do not likely originate from unprocessed CD16a in the ER because all of the observed hybrid forms were sialylated, a modification that occurs in the late Golgi compartments (113) (Figure 3). Moreover, the presence of oligomannose type $\mathrm{N}$-glycans on CD16a from almost all recombinant sources suggests that restricted processing is a conserved feature (108-110). N-glycans at Asn38 and Asn74 were not observed using this glycomics approach to study NK cell CD16a; perhaps these large glycans ionize too poorly to be observed in a derivatized form, but robust ionization of the peptide provides measurable signals for CD16b N38 and N74 glycopeptides (111).

Recombinant expression has thus far failed to generate CD16 with glycan profiles matching those measured for CD16a or CD16b from primary cells. CD16a is the most heavily studied $\mathrm{Fc} \gamma \mathrm{R}$ due to its role in ADCC and the associated therapeutic applications. Glycomics characterization of soluble extracellular domain of CD16a (sCD16a) from HEK293, NS0, and CHO cell lines showed stark differences when compared to CD16a from NK cells, including a high abundance (over $90 \%$ compared to $55 \%$ in NK cells) of biantennary and triantennary complex type $\mathrm{N}$-glycans with low levels of sialylation (108-110). Moreover, each recombinant system has the potential to synthesize unique $\mathrm{N}$-glycan structures that are not commonly found on native human proteins, such as LacDiNAc (GlcNAc-GalNAc) from HEK293 cells, $\alpha$-Gal epitopes ( $\alpha$ Gal- $\beta$ Gal- $\beta$ GlcNAc), terminal Nacetylglycolylneuraminic acid in NS0 cells and only $\alpha-2,3$ linked sialic acids in CHO cells $(106,114)$. These terminal modifications can potentially alter the binding affinity to IgG in an unexpected and undesirable manner.

Differences between native and recombinant CD16a processing render studies of binding affinity using recombinant material suboptimal, however, these materials still represent the best option for many in vitro studies. Furthermore, binding affinity measurements have utilized the soluble extracellular Fc $\gamma \mathrm{R}$ domains due to challenges associated with extracting full-length material from the membrane. Tethering CD16a to the membrane changes the N-glycosylation, likely due to differential localization within the Golgi $(88,109)$. Unfortunately, the N-glycosylation profile of full-length CD16a (frCD16a) expressed with HEK293 cells revealed an N-glycan profile unlike that found on NK cells (109). N-glycans from frCD16a showed less under-processed oligomannose and hybrid types (27\% in frCD16a and $45 \%$ in NK cell CD16a) and the complex-type N-glycans were highly branched. Thus, cell-type specific glycosylation accounts for the dissimilar N-glycan profile on CD16a from primary and recombinant sources and impacts binding affinity measurement, as discussed below.

Recombinant $F_{c} \gamma$ Rs are valuable to characterize the role of $\mathrm{N}$-glycosylation on IgG binding affinity, despite clear differences in N-glycan processing when compared to endogenous material. One recent study reported a 40 -fold increase in affinity toward afucosylated IgG1-Fc (G0 form) when complex type N-glycans on CD16a were replaced with $\mathrm{Man}_{5} \mathrm{~N}$-glycans (110). This gain revealed that CD16a can bind with an affinity comparable to CD64, the "high affinity Fc $\gamma \mathrm{R}$." A comparable study demonstrated that higher amounts of larger sialylated complex type $\mathrm{N}$-glycans on CD16a expressed in CHO cells correlated with lower affinity for Rituximab (108).

Of five CD16a N-glycans, only two appear essential for high affinity interactions. Mutating the protein to eliminate Nglycan addition with N45Q and N162Q substitutions reduced the affinity for IgG1-Fc (109, 115-117). However, the reported influence of $\mathrm{N}$-glycan composition was primarily driven by the N-glycan at N162: only the N162Q mutation abolished the affinity gain due to $\mathrm{Man}_{5} \mathrm{~N}$-glycans on CD16a (110). These observations are in agreement with the fact that glycans at N45 
and N162 form interactions with the CD16a polypeptide and influence protein structure (118) and glycans at these two sites showed the greatest restriction in $\mathrm{N}$-glycan processing using the HEK293 and CHO systems (119). Thus, cell-type specific CD16a $\mathrm{N}$-glycosylation patterns influence affinity for IgG1 and a range of potential affinities are accessible purely through modifying $\mathrm{N}$-glycan processing.

\section{$\mathrm{N}$-glycosylation of CD16b}

$\mathrm{CD} 16 \mathrm{~b}$ is a highly similar paralogue of CD16a and only found in humans (97\% sequence homology of the extracellular antibodybinding domain). However, two common CD16b alleles encode either four (NA1) or six (NA2) N-glycosylation sites (120, 121) (Figure 2). Considerable site-specific diversity in N-glycan structures was present on $\mathrm{sCD} 16 \mathrm{~b}$ obtained from $2 \mathrm{l}$ of pooled human serum (111). Serum sCD16b is generated by ADAM17 cleavage of cell surface CD16b upon neutrophil activation (48). Thus, sCD16b were likely membrane bound when the N-glycans were being processed. The $\mathrm{N}$-glycans at each site had unique profiles ranging from smaller oligomannose type $\mathrm{N}$-glycans at N45 to large complex type $\mathrm{N}$-glycans with extensive elongation, sialylation, and fucosylation at N38 and N74, unlike sCD16b expressed in recombinant systems $(106,114,122)$. Additionally, allele specific (NA1 and NA2) N-glycosylation profile at N162 and N45 of donor matched serum and neutrophil CD16b confirmed the observations of CD16b from pooled serum, revealing moderate variability in the abundance of the most prominent glycoforms (123). The profile of sCD16b from serum was distinct from CD16a expressed by NK cells that displayed a greater level of under-processed N-glycans $(109,111)$. The presence of oligomannose type $\mathrm{N}$-glycans only at N45 strongly suggests under-processing of $\mathrm{N}$-glycan is restricted to a single site on the protein with as many as six $\mathrm{N}$-glycosylation sites (111).

The stark differences in the glycosylation profile of $\mathrm{sCD} 16 \mathrm{~b}$ from serum compared to recombinant $\mathrm{sCD} 16 \mathrm{~b}$ further emphasized the importance of cell type specific $\mathrm{N}$-glycosylation. Glycomics analysis of CD16b from HEK293, NS0 and BHK revealed mainly multiantennary complex type $\mathrm{N}$-glycans with a high degree of sialylation and fucosylation $(106,114,122)$. The $\mathrm{N}$-glycosylation profile of recombinant sCD16a and sCD16b are comparable as most of the $\mathrm{N}$-glycosylation sites are shared (124). There was a minimal difference (2-fold increase) in affinity when sCD16b-Man5 binding to IgG1-Fc (G0F form) was compared to sCD16b with complex-type N-glycans (110). This was surprising considering that the extracellular antibody binding domains of CD16a and CD16b (NA2) differ at only four amino acid residues. Moreover, both CD16s are functionally distinct because CD16a-complex type has a 15 -fold greater affinity for IgG-Fc than CD16b-complex type (110). The affinity and sensitivity to glycan composition for CD16b was improved to that of CD16a by mutating a single residue, Asp129, to Gly based on the CD16a sequence (124). The authors demonstrate with $\mathrm{x}$-ray crystallography and molecular dynamics simulations that Asp129 buckles the CD16b backbone upon binding IgG1 Fc. Thus, buckling shifts a nearby residue, Arg155, which makes a different contact with the N162-glycan that is not observed in CD16a.

\section{$\mathrm{N}$-glycosylation of CD32}

The N-glycosylation profiles of sCD32a and $\mathrm{sCD} 32 \mathrm{~b}$ expressed with recombinant systems were highly comparable $(106,108$, 114). There are two to three N-glycosylation sites on CD32: CD32a (3), CD32b (2), and CD32c (2; 32b and 32c have identical extracellular domains) (Figure 2). Glycomics analysis of CD32a and CD32b expressed in HEK293, NSO, and CHO displayed predominantly biantennary and triantennary complex type $\mathrm{N}$-glycan structures with a low degree of sialylation and varying levels of fucose $(106,108,110,114)$. Binding affinity between $\mathrm{sCD} 32 \mathrm{a}$ and $\mathrm{sCD} 32 \mathrm{~b}$ was comparable and neither appeared sensitive to $\mathrm{N}$-glycan composition as $\mathrm{sCD} 32$ (a or b)Man5 and sCD32(a or b)-complex type bound IgG1 Fc with similar affinities $(106,110)$. CD32a polymorphisms (R131 or H131) cause differences in binding to IgG subtypes, potentially changing the sensitivity of immune complexes to phagocytosis by neutrophils and monocytes $(121,125)$. However, N-glycan analysis on the receptor expressed in $\mathrm{CHO}$ cells showed no substantial difference in glycosylation pattern between the two CD32a allotypes (108). The site-specific N-glycosylation profile and native $\mathrm{N}$-glycosylation profile for any CD32 is not currently available.

\section{$\mathrm{N}$-glycosylation of CD64 Also Impacts Binding Affinity}

The high affinity Fc $\gamma \mathrm{R}, \mathrm{CD} 64$, is distinct from other Fc $\gamma \mathrm{Rs}$ because it contains an additional extracellular domain (126). Moreover, CD64 can potentially receive N-glycosylation modification at seven sites in its extracellular domain (Figure 2). A comparative glycomics analysis of the sCD64 expressed in HEK293, NS0, and CHO cell lines showed biantennary and multi-antennary complex type $\mathrm{N}$-glycans with varying degrees of sialylation and fucosylation as the most abundant glycoforms $(106,108,114)$. A distinct feature which was conserved across sCD64 expressed in all three cell lines was the higher abundance of oligomannose structures when compared to recombinant CD16 or CD32. It was speculated that the presence of Man 5 forms (the most abundant oligomannose N-glycan in these cell types) conferred a stabilizing effect toward IgG1 binding since the higher abundance of $\mathrm{Man}_{5}$ forms (14.4\% in NS0 and $5.2 \%$ in $\mathrm{CHO}$ ) correlated with an increase in binding affinity to Rituximab (108). According to the authors, the increased affinity was due to the lack of core fucose on the $\mathrm{Man}_{5}$ structure which can potentially prevent steric hindrance effects similar to that observed in fucosylated N-glycan on IgG1 $(115,127)$. The authors also observed that the presence of large sialylated complex type N-glycans on CD64 correlated with reduced binding affinity for Rituximab, indicating that these glycans destabilized the interaction (108). Even though $\mathrm{N}$-glycan composition on CD64 can affect IgG1 affinity, the $\mathrm{N}$-glycosylation profile of native CD64 and the composition of $\mathrm{N}$-glycans at each site remains unknown.

$\mathrm{N}$-glycosylation processing depends on the amino acid sequence and secondary structures which affect the exposure of substrate monosaccharide residues to the glycan processing enzymes (Figure 3). Presence of both the under-processed and 
highly-processed (tetraantennary sialylated) N-glycan structures on NK cell CD16a and recombinant sCD64 suggests site-specific glycan modification. Oligomannose structures at specific sites on sCD16a have been implicated in modulating IgG affinity; similarly, specific sites on CD64 can be involved in modulating CD64-IgG1 affinity $(108,110)$. Thus, a thorough analysis of site-specific $\mathrm{N}$-glycosylation analysis of recombinant and endogenous $\mathrm{Fc} \gamma$ Rs from all expressing tissues is required to fully elucidate the role of $\mathrm{N}$-glycosylation pattern at specific sites in affinity modulation.

\section{HOW MULTIVALENCY IMPACTS IgG-Fc $\gamma$ R INTERACTIONS}

Investigating factors that contribute to the monovalent affinity of IgG-Fc $\gamma$ Rs interaction revealed clear differences in the affinity of antibody subclasses for certain receptors, however, multivalent avidity likely determines the in vivo immunological response initiated by these interactions. High IgG concentrations in the serum of $\sim 10 \mathrm{mg} / \mathrm{ml}$ provide monomeric antibody to the receptors at a concentration of $\sim 67 \mu \mathrm{M}$, vastly exceeding the $K_{\mathrm{D}}$ of IgG1 for all human receptors (7). Thus, surfaceborne Fc $\gamma$ Rs are occupied on cells circulating in the peripheral compartment and multivalent interactions must compete with monomeric IgG to cluster receptors $(7,8)$. Receptor crosslinking and clustering on the effector cell surface is essential for signal transduction through Fc $\gamma$ Rs, thus multivalent immune complexes or opsonized targets are the functionally appropriate ligands for the receptors (Figure 1) (54, 128). Distinct Fc $\gamma$ Rs are engaged depending on the responding cell type, the IgG subclass, the antibody concentration on the opsonized target, and the size of immune complex (Figures 1, 2) (129, 130). Furthermore, the differential binding of immune complexes has therapeutic as well as pathogenic properties, especially during infection and autoimmune disease but not all aspects are well-defined $(9,15)$. Therefore, defining the critical factors associated with immune complex recognition is required to fully understand the antibodymediated immune response.

\section{Immune Complex Size Determines Effector Function}

The importance of interactions between multiple monovalent ligands and multiple receptors is well known, however, the study of multivalent interactions remains challenging. Early attempts to generate multivalent immune complexes through heat aggregation of IgG produced aggregates with varied valency, immunogenicity and ill-defined sizes $(131,132)$. Technological advances in recent years produced immune complexes of defined size and valency which accurately represent those generated in vivo (130). Functional interrogation using defined immune complex revealed that immune complex size contributes to interactions with Fc $\gamma$ Rs.

\section{Immune Complex Size Affects Binding}

The concentration of antigen-specific antibody in the serum and likewise immune complex size is expected to change during an immune response, and size-associated changes in the immune response are well described $(130,133)$. Nimmerjahn and coworkers used well-defined immune complexes formed by all four IgG subclasses binding to Fc $\gamma$ Rs expressed on a $\mathrm{CHO}$ cell surface to systematically determine that there was a clear size-dependent gain in binding by IgG2 and IgG4 immune complexes and the size of an immune complex can overcome IgG glycan truncation, a modification that destroys the monovalent interaction (134). Moreover, the binding patterns were comparable to experiments using primary leukocytes that increased cytokine secretion in response to larger immune complexes. These data led to a mathematical model that describes effects of valency and IgG subclass on in vivo function (135). The differential binding due to a change in the size of immune complex can potentially lead to substantial changes in cell signaling and recent technical advances provide a means to quantitate signaling with cell-based assays (136).

\section{Role of Immune Complex Size in Autoimmune Disorders}

The formation of immune complexes with soluble self-antigen is implicated in the pathophysiology of several autoimmune diseases (137). IVIG is a frequent treatment for a variety of autoimmune disorders, but the exact mechanism of action is not known (138). Even though there is a well-documented role of $\mathrm{CD} 32 \mathrm{~b}$ in decreasing an immune response triggered by autoantibody immune complexes in murine model of immune thrombocytopenia (ITP) (139), a recent study demonstrated that engaging the inhibitory $\mathrm{CD} 32 \mathrm{~b}$ alone is not responsible for the decrease in phagocytosis of RBC opsonized by autoantibody in human ITP patients. Instead, the direct engagement of IgG by CD64 and CD32a caused the decrease in phagocytosis (140). Surprisingly, though IVIG dimers and multimers are not necessary for therapeutic efficacy in murine models for ITP, small IVIG oligomers provided more potent inhibition of phagocytosis, indicating a role of IVIG immune complexes in blocking pathogenic immune complexes from binding to activating Fc $\gamma$ Rs (141). Consistent with this observation, immune complexes formed with the anti-citrullinated protein antibodies isolated from rheumatoid arthritis patients bound preferentially to activating and not inhibiting $\mathrm{Fc} \gamma \mathrm{Rs}$ expressed on $\mathrm{CHO}$ cells (142). Moreover, CD64 on activated neutrophils and CD32a on macrophages were recognized as receptors for the autoantibody immune complex, eliciting the secretion of proinflammatory cytokines. These observations formed the basis for developing engineered multivalent immune complexes as therapeutic options.

\section{Considerations Regarding Immune Complex Size in Therapeutic Development}

Multivalent synthetic immune complexes show promise and may prove useful in the clinic. For example, a trivalent IgG-Fc construct inhibited autoantibody-mediated Fc $\gamma$ Rdependent cellular responses in primary human cells and autoimmune murine models (143). Likewise, an engineered hexameric-Fc construct bound to primary differentiated human macrophages and triggered internalization, colocalizing 
with the activating $\mathrm{Fc} \gamma \mathrm{Rs}$ and elicited a decrease in the phagocytosis of antiCD20-coated human B cells and platelets in a murine ITP model (144). The hexameric Fc construct did not trigger internalization of CD32b and exhibited a much shorter serum half-life in animal models than IgG1, however, the inhibition was effective for several days after the initial injection, suggesting a potential for clinical use. In contrast to the approach of preventing the internalization of pathogenic immune complex to block phagocytosis of healthy cells or activating a pro-inflammatory response, a designed bispecific antibody formed larger complexes that neutralized soluble antigens, leading to rapid clearance from serum of a murine model (145). Thus, studies of multivalent $\mathrm{IgG}-\mathrm{Fc} \gamma \mathrm{R}$ interactions provide guidance for the development of effective therapeutic options. However, there are multiple antibody and antigen associated factors which govern the antigenicity of immune complexes that must be considered when designing antibodies with defined Fc $\gamma$ R-dependent functions.

\section{Features of the Antibody and Antigen That Impact Antigenicity of the Immune Complex in vivo \\ The Ratio of Antibody to Antigen}

Antibody concentration relative to antigen changes throughout the progression of an immune response against an infectious pathogen. Considering influenza infection as an example, the Bcell response can take up to 7-14 days to produce antibodies (146). Generally, the antigen-specific antibody titers increased by up to 10.2-fold, depending on the patient, vastly changing the antibody to antigen ratio and the antibody production can be sustained or subside depending on clearance of the organism.

A minimal threshold of antibody density must be surpassed to elicit an immune response during encounters between an opsonized target and effector cell, typically seen during pathogenic infection $(147,148)$. Antibody concentrations that exceed the threshold lead to an increase in phagocytic activity, as demonstrated by primary mouse bone marrow derived macrophages phagocytosing opsonized sheep erythrocytes. Moreover, at relatively high concentrations of $\operatorname{IgG}$, a valency dependent induction of IL-10 production was seen (148). Similarly, infection with Cryptococcus neoformans in mice could be cleared using a specific ratio of antibody to antigen, ratios with excessive antibody led to a detrimental host response mainly due to a reduction in pro-inflammatory cytokines secretion in organs associated with the infection (149). Apart from changes in cytokine secretion potential, larger immune complexes formed with high concentrations of neutralizing antibody against dengue virus actually inhibited antibody-dependent enhancement by binding to the inhibitory receptor $\mathrm{CD} 32 \mathrm{~b}$ on phagocytic monocytes (150). Thus, relative antibody concentration can modulate immune response in an $\mathrm{F} c \gamma \mathrm{R}$-dependent manner by altering the size and concentration of immune complexes; this effect may be similar to the therapeutic benefit of IVIG in autoimmune conditions.

\section{Concentration of the Immune Complex}

Immune complex concentration likewise impacts viral infection. Apart from the traditional view of Fab-mediated neutralizing activity, Fc dependent effector functions are becoming increasingly recognized in protection against viral infection $(16,17,151)$. Classical Fc $\gamma \mathrm{R}$-dependent protective mechanisms such as ADCC and ADCP, as well as antibody dependent enhancement of infection, are influenced by the size of the immune complex and IgG subtype coating the viral particle $(17,152)$. The production of a high concentration of immune complexes are common during chronic viral infection in mice (153). However, high concentrations do not always lead to favorable outcomes. A high concentration of immune complex blocked Fc $\gamma$ Rs on primary murine macrophages and dendritic cells, negatively impacting viral clearance, and other Fc $\gamma$ Rrelated activity (153). These phenomena were independent of $\mathrm{CD} 32 \mathrm{~b}$ and reversed once the immune complex concentration was reduced. Thus, the role of Fc $\gamma$ Rs during pathogen infection is complex and varied but there is a clear dependence of cellular response based on immune complex size and concentration, similar to that observed in autoimmune disease discussed above.

\section{Affinity of the Antibody for Antigen}

At a fixed antibody concentration, the affinity of the antibody toward the antigen can determine how many Fcs are displayed on the immune complex and are available to interact with Fc $\gamma$ Rs (154). A recent study showed that at saturating concentrations, antibodies with high affinity for antigen elicited a weaker ADCC response compared to antibodies with lower affinity $\left(K_{\mathrm{D}}=\right.$ $0.8 \mathrm{nM}$ and $72 \mathrm{nM}$, respectively) (155). The observed difference in the immune response was attributed to the higher proportion of monovalent antigen binding displayed by the lower affinity antibody, recruiting a larger number of antibodies to the cell surface and increasing the number of Fcs available to the leukocyte. A notable feature of this observation is the initial IgG response often produces antibodies with antigen-binding affinities similar to the lower affinity antibody in this study. Antibody concentration and antibody-antigen affinity are not the only factors affecting immunogenicity of immune complex. A comparative analysis of three anti-TNF $\alpha$ antibodies with a range of affinities $\left(K_{\mathrm{D}}=0.18-5.1 \mathrm{nM}\right)$ showed that the size and composition of the immune complex was determined by the properties associated with epitope location and binding energetics (156).

\section{Epitope and Antigen Location}

Location of the epitope influences the immune response. Neutralizing antibodies targeting the stalk region of the influenza hemagglutinin protein induced Fc $\gamma \mathrm{R}$-dependent cytotoxicity while antibodies binding the head domain did not (12). A comparable analysis of anti-Ebola antibodies showed that binding to the most membrane distal portion of viral surface glycoprotein elicited the highest ADCP and antibody-dependent neutrophil phagocytosis (ADNP) compared to antibodies that bound to the membrane proximal regions (157). Even though epitope location on the antigen is not directly implicated in changes in immune complex size in these studies, it is likely 
that the epitope location causes changes in immune complex properties since three different monoclonal antibodies against different epitopes on $\mathrm{sCD} 154$ and $\mathrm{TNF} \alpha$ also formed different immune complexes $(156,158)$. In other cases, the height of the antigen from the target surface affected phagocytosis in a valency-independent manner (55). Antigens which are $<10 \mathrm{~nm}$ from target surface promoted phagocytosis when compared to antigens further away from the surface because close contact between target and effector cell surface was necessary to exclude effector cell the inhibitory CD45 from the immune synapse following Fc $\gamma$ Rs clustering (as noted above). Additionally, antibodies binding West Nile virus epitopes that are normally buried can form immune complexes, given sufficient incubation time, though these immune complexes are smaller and led to lower neutralization levels (154). Thus, location of the epitope can affect the immune response but the effect of epitope location on immune complex size is not fully understood.

The location of the antigen (soluble or cell bound) affects $\mathrm{Fc} \gamma \mathrm{R}$ clustering and the subsequent immune response. A soluble antigen may form relatively smaller immune complexes which are endocytosed but a cell surface antigen forms a relatively larger opsonized target that is more likely phagocytized as determined using mouse bone marrow-derived macrophages (133). Both mechanisms, triggered through $\mathrm{Fc} \gamma \mathrm{Rs}$, are distinct and induce different signaling and subsequent immune responses $(128,159)$. In one example, small soluble immune made with soluble CD154 would be expected to be endocytosed, and CD154 tethered to a T cell membrane led to the formation of very large complexes at the cell surface (158). Surprisingly, the specific monoclonal antibody greatly influenced the immune complex structure. It is also known that opsonized targets can exhibit lateral diffusion on the leukocyte surface which also affects the multivalent interaction with Fc $\gamma$ Rs (160).

\section{Malleable vs. Rigid Target Surfaces}

In addition to size and shape, deformability of the target also impacts activation. The phagocytosis of opsonized polyacrylamide beads tuned to exhibit different rigidity established that phagocytosis of ridged particles was preferred over relatively more deformable particles by mouse bone marrow-derived macrophages (161). A related study demonstrated that murine macrophage RAW264.7 cells phagocytosed emulsion droplets at a lower IgG concentration when compared to solid particles (162). It was speculated that the attachment of IgG on the surface of rigid particles prevents the lateral diffusion of opsonizing antibodies, while lateral diffusion was observed in opsonized emulsion droplet. Thus, the location of the antigen, which facilitated higher cell surface Fc $\gamma$ Rs interaction at lower antibody concentrations, can affect recognition of the complex.

\section{IgG-Subclass Impact Immune Response}

$\mathrm{Fc} \gamma \mathrm{R}$ binding is also affected by IgG subclass. Specificity of a specific IgG subclass binding to a Fc $\gamma \mathrm{R}$ is largely studied in context of a monovalent interaction (23), however, immune complexes and opsonized target cells are the natural ligands. Additionally, specific IgG subclasses are related to various disorders indicating immune complex composition is important $(1,152,163)$. Therefore, studying these interactions in a multivalent form is required to accurately determine their binding properties and the subsequent immune response. The observation that immune complexes of certain IgG subclasses only bind at higher concentrations indicates that IgG subclass is also a variable which can affect the immune response (164).

The Fcs of different IgG subclasses have distinct amino acid residues and hinge regions which can affect binding to the $\mathrm{Fc} \gamma \mathrm{Rs}$, despite a high degree of sequence conservation (Figure 2) (1). A systematic analysis of multivalent binding for the four human IgG subclasses to the cell surface Fc $\gamma$ Rs revealed the IgG2 and IgG4 subclasses, which showed minimal affinity in a monovalent interaction, bound as immune complexes to $\mathrm{Fc} \gamma \mathrm{Rs}$ expressed on $\mathrm{CHO}$ cells at higher concentrations (164). This study also demonstrated that allotype variants of Fc $\gamma$ Rs had different binding properties toward immune complexes generated by different IgG subtypes. CD16a V158 bound IgG3 immune complexes with high affinity while CD16a F158 bound more weakly and CD32a H131 had a higher affinity to IgG2 immune complex compared to CD32a R131. Another report showed that the CD32a H131 variant bound to IgG1, IgG2, and IgG3 with higher affinity than CD32a R131. This observation may explain why the CD32a R131 allotype is associated with greater susceptibility to bacterial infections and autoimmune disorders (163). Thus, the wide range of binding affinities displayed by Fc $\gamma$ Rs toward IgG subclass specific immune complexes can impact clinical outcome.

The use of different IgG subclasses in designed immune complexes can also impact potential therapeutic use. Incubation of a hexameric IgG1 Fc construct, discussed above as an inhibitor of phagocytosis, elicited the release of higher cytokine levels in whole blood when compared to PBMCs, likely due to CD16b engagement on neutrophils (not present in PBMCs) (165). Furthermore, the hexameric IgG1 Fc construct also triggered release of cytokines from platelets through a CD32a-dependent interaction. However, a hexameric IgG4 Fc construct did not promote the release of cytokines from neutrophils or platelets. This result is consistent with the reduced affinity of IgG4 for CD16b and CD32a when compared with IgG1, highlighting the potential utility of specific Fc $\gamma$ R interactions.

\section{SUMMARY}

The multitude of factors influencing the immune system each affects a wide range of responses. This review covers a relatively limited collection of variables that contribute to an Fc $\gamma \mathrm{R}$ dependent immune response (Figure 1). There appear to be few inviolable laws governing this aspect of the immune system, and every newly discovered variable introduce a new handle to tune the immune response, at least in vitro. It is well known that different monoclonal antibodies to a single target elicit different responses, in many cases through the mechanisms described here. If any lessons are to be learned, it is that each antibody must be thoroughly evaluated using systems that recapitulate as closely as possible endogenous immune system components. 
One striking example of this tenet is the observation that the efficacy of a hexameric IgG1 Fc increased when neutrophils and platelets were incorporated in an in-vitro assay with PBMCs (165). Moreover, soluble complement components can also bind the immune complex to affect the immune response as reported in few studies described above (130, 148, 149). Laboratory studies often focus on immune complexes formed by monoclonal antibodies, but that is likely not the case in vivo with a polyclonal immune response to vaccines or infection; one study demonstrated that a mixture of disease neutralizing and disease enhancing antibodies against Bacillus anthracis formed immune complexes that elicited a protective immune response (166). Thus, these observations highlight the complex yet important features associated with studying Fc $\gamma$ Rs function in vivo.

Animal models have, and will continue to have, an important role in studies designed to understand human Fc $\gamma$ Rs in immune function. Despite the differences in $\mathrm{F} c \gamma \mathrm{R}$ cellular expression patterns and minor differences in binding affinities to human IgG subclass, animal (mainly murine and non-human primate) models have sufficiently recapitulated human Fc $\gamma \mathrm{R}$ biology to be used for studying Fc $\gamma \mathrm{R}$ function and test therapeutic molecules (167-173). A recent study determined that the mouse Fc $\gamma$ RIV and the human equivalent to human CD16a both share the conserved N-glycosylation site at N162 which mediates tight binding to afucosylated mouse IgG similar to observations in human system, and human IgG binds mouse Fc $\gamma$ Rs with similar affinity patterns as human Fc $\gamma$ Rs demonstrating conservation of certain functional features of human $\mathrm{Fc} \gamma \mathrm{R}$ biology in mouse model $(170,174)$. Furthermore, several studies mentioned in this review have employed murine autoimmune models, humanized models, cell lines or primary cells to test efficacy of engineered antibody products and delineate mechanistic aspects of the Fc $\gamma$ Rs dependent cellular response, demonstrating that these models are indispensable for understanding human Fc $\gamma R$ biology $(61,66,139,141,143,162)$. The two successful strategies to attain humanized $\mathrm{Fc} \gamma \mathrm{R}$ mouse models eliminate the influence of mouse $\mathrm{F} c \gamma$ Rs in studying human $\mathrm{Fc} \gamma \mathrm{R}$ function

\section{REFERENCES}

1. Vidarsson G, Dekkers G, Rispens T. IgG subclasses and allotypes: from structure to effector functions. Front Immunol. (2014) 5:520. doi: 10.3389/fimmu.2014.00520

2. Bolland S, and Ravetch JV. Inhibitory Pathways triggered by ITIM-containing receptors. Adv Immunol. (1999) 72:149-77. doi: 10.1016/S0065-2776(08)60019-X

3. Isakov N. Immunoreceptor tyrosine-based activation motif (ITAM), a unique module linking antigen and $\mathrm{Fc}$ receptors to their signaling cascades. J Leukocyte Biol. (1997) 61:6-16. doi: 10.1002/jlb.61.1.6

4. Li X, Wu J, Ptacek T, Redden DT, Brown EE, Alarcón GS, et al. Allelic-dependent expression of an activating Fc receptor on B cells enhances humoral immune responses. Sci Transl Med. (2013) 5:216ra175. doi: 10.1126/scitranslmed.3007097

5. Turner M, Schweighoffer E, Colucci F, Di Santo JP, Tybulewicz VL. Tyrosine kinase SYK: essential functions for immunoreceptor signalling. Immunol Today (2000) 21:148-54. doi: 10.1016/S0167-5699(99)01574-1

6. Nimmerjahn F, Ravetch JV. Fcy receptors: old friends and new family members. Immunity (2006) 24:19-28. doi: 10.1016/j.immuni.2005.11.010 in these models and can uncover novel role of Fc $\gamma$ Rs in autoimmune disorders, infection and cancer immunity (175, 176). However, important yet undefined $\mathrm{Fc} \gamma \mathrm{R}$ variables including post-translational modification including glycosylation as well as copy number variation and interaction with coexpressed membrane proteins likely vary in animal models. It is likely that organism diversity in these key variables likewise differentially impacts immune function, comparable to the diversity attributed to protein coding regions and gene variability between species.

It is worth highlighting the role of post translation modification of the Fc $\gamma$ Rs as another critical variable that is overlooked due to the historical inability to resolve differences in the glycosylation of endogenous material. One future challenge will be matching the level of detail known regarding serum IgG glycosylation with studies of functionally-relevant $\mathrm{Fc} \gamma \mathrm{R}$ modifications as these have the potential to exert an enormous influence on the immune response. Differential gene expression profiles of the glycan modifying enzymes are present in monocytes, dendritic cells, and macrophages, suggesting the potential for the functionally-relevant differentiation and maturation specific N-glycosylation modifications (177). A complete understanding of the immune response will require the definition of these recently discovered variables, with the likelihood that more variables will emerge.

\section{AUTHOR CONTRIBUTIONS}

All authors listed have made a substantial, direct and intellectual contribution to the work, and approved it for publication.

\section{ACKNOWLEDGMENTS}

This material is based upon work supported by the National Institutes of Health under Award No. R01 GM115489 (NIGMS) and by the Roy J. Carver Department of Biochemistry, Biophysics \& Molecular Biology at Iowa State University.

7. Kelton JG, Singer J, Rodger C, Gauldie J, Horsewood P, Dent P. The concentration of IgG in the serum is a major determinant of Fc-dependent reticuloendothelial function. Blood (1985) 66:490-5.

8. Mirre E, van Teeling JL, Meer JWM, Bleeker WK, Hack CE. Monomeric IgG in intravenous Ig preparations is a functional antagonist of Fc $\gamma$ RII and Fc $\gamma$ RIIIb. J Immunol. (2004) 173:332-9. doi: 10.4049/jimmunol.173 .1 .332

9. Li X, Kimberly RP. Targeting the Fc receptor in autoimmune disease. Exp Opin Ther Targets (2014) 18:335-50. doi: 10.1517/14728222.2014.877891

10. Boross P, van Montfoort N, Stapels DAC, van der Poel CE, Bertens C, Meeldijk J, et al. FcR $\gamma$-chain ITAM signaling is critically required for crosspresentation of soluble antibody-antigen complexes by dendritic cells. $J$ Immunol. (2014) 193:5506-14. doi: 10.4049/jimmunol.1302012

11. Daëron M. Fc Receptor biology. Ann Rev Immunol. (1997) 15:203-34. doi: 10.1146/annurev.immunol.15.1.203

12. DiLillo DJ, Tan GS, Palese P, Ravetch JV. Broadly neutralizing hemagglutinin stalk-specific antibodies require $\mathrm{Fc} \gamma \mathrm{R}$ interactions for protection against influenza virus in vivo. Nat Med. (2014) 20:143-51. doi: 10.1038/nm.3443

13. Vogelpoel LTC, Baeten DLP, de Jong EC, den Dunnen J. Control of cytokine production by human fc gamma receptors: implications 
for pathogen defense and autoimmunity. Front Immunol. (2015) 6:79. doi: 10.3389/fimmu.2015.00079

14. Weiskopf K, Weissman IL. Macrophages are critical effectors of antibody therapies for cancer. MAbs (2015) 7:303-10. doi: $10.1080 / 19420862.2015 .1011450$

15. Bournazos S, DiLillo DJ, Ravetch JV. The role of $F c-F c \gamma R$ interactions in IgG-mediated microbial neutralization. J Exp Med. (2015) 212:1361-9. doi: 10.1084/jem.20151267

16. Chan KR, Ong EZ, Mok DZ, Ooi EE. Fc receptors and their influence on efficacy of therapeutic antibodies for treatment of viral diseases. Exp Rev Anti Infect Ther. (2015) 13:1351-60. doi: 10.1586/14787210.2015.10 79127

17. Lu LL, Suscovich TJ, Fortune SM, Alter G. Beyond binding: antibody effector functions in infectious diseases. Nat Rev Immunol. (2018) 18:46-61. doi: 10.1038/nri.2017.106

18. Lyden TW, Robinson JM, Tridandapani S, Teillaud JL, Garber SA, Osborne JM, et al. The Fc receptor for IgG expressed in the villus endothelium of human placenta is Fc gamma RIIb2. J Immunol. (2001) 166:3882-9. doi: 10.4049/jimmunol.166.6.3882

19. Simister NE, Story CM, Chen H-L, Hunt JS. An IgG-transporting Fc receptor expressed in the syncytiotrophoblast of human placenta. Eur J Immunol. (1996) 26:1527-31. doi: 10.1002/eji.1830260718

20. Wainwright SD, Holmes CH. Distribution of Fc gamma receptors on trophoblast during human placental development: an immunohistochemical and immunoblotting study. Immunology (1993) 80:343-51.

21. Okayama Y, Kirshenbaum AS, Metcalfe DD. Expression of a functional highaffinity IgG receptor, Fc $\gamma \mathrm{RI}$, on human mast cells: up-regulation by IFN- $\gamma$. J Immunol. (2000) 164:4332-9. doi: 10.4049/jimmunol.164.8.4332

22. Cassatella MA, Flynn RM, Amezaga MA, Bazzoni F, Vicentini F, Trinchieri G. Interferon gamma induces in human neutrophils and macrophages expression of the mRNA for the high affinity receptor for monomeric IgG (Fc gamma R-I or CD64). Biochem Biophys Res Commun. (1990) 170:582-8. doi: 10.1016/0006-291X(90)92131-I

23. Ravetch JV, Kinet JP. Fc receptors. Annu Rev Immunol. (1991) 9:457-92. doi: 10.1146/annurev.iy.09.040191.002325

24. Rosales $\mathrm{C} . \mathrm{Fc} \gamma$ receptor heterogeneity in leukocyte functional responses. Front Immunol. (2017) 8:280. doi: 10.3389/fimmu.2017.00280

25. Chauhan AK, Chen C, Moore TL, DiPaolo RJ. Induced expression of Fc $\gamma$ RIIIa (CD16a) on CD4+ T cells triggers generation of IFN- $\gamma$ high subset. J Biol Chem. (2015) 290:5127-40. doi: 10.1074/jbc.M114.599266

26. Ravetch JV, Bolland S. IgG Fc Receptors. Annu Rev Immunol. (2001) 19:27590. doi: 10.1146/annurev.immunol.19.1.275

27. Ravetch JV, Perussia B. Alternative membrane forms of Fc gamma RIII(CD16) on human natural killer cells and neutrophils. Cell type-specific expression of two genes that differ in single nucleotide substitutions. J Exp Med. (1989) 170:481-97. doi: 10.1084/jem.170.2.481

28. Meknache N, Jönsson F, Laurent J, Guinnepain M-T, Daëron M. Human basophils express the glycosylphosphatidylinositol-anchored lowaffinity igg receptor FcyRIIIB (CD16B). J Immunol. (2009) 182:2542-50. doi: $10.4049 /$ jimmunol.0801665

29. Davoine F, Lavigne S, Chakir J, Ferland C, Boulay M-Ė, Laviolette M. Expression of FcyRIII (CD16) on human peripheral blood eosinophils increases in allergic conditions. J Allergy Clin Immunol. (2002) 109:463-9. doi: $10.1067 /$ mai.2002.121952

30. Zhu X, Hamann KJ, Muñoz NM, Rubio N, Mayer D, Hernrreiter A, et al. Intracellular Expression of Fc $\gamma$ RIII (CD16) and its mobilization by chemoattractants in human eosinophils. J Immunol. (1998) 161:2574-9.

31. Anderson CL, Ganesan LP, Robinson JM. The biology of the classical Fc $\gamma$ receptors in non-hematopoietic cells. Immunol Rev. (2015) 268:236-40. doi: 10.1111/imr.12335

32. Breunis WB, van Mirre E, Geissler J, Laddach N, Wolbink G, van der Schoot E, et al. Copy number variation at the FCGR locus includes FCGR3A, FCGR2C and FCGR3B but not FCGR2A and FCGR2B. Hum Mutat. (2009) 30:E640-50. doi: 10.1002/humu.20997

33. Morris DL, Roberts AL, Witherden AS, Tarzi R, Barros P, Whittaker JC, et al. Evidence for both copy number and allelic (NA1/NA2) risk at the FCGR3B locus in systemic lupus erythematosus. Eur J Hum Genet. (2010) 18:1027-31. doi: 10.1038/ejhg.2010.56
34. Niederer HA, Clatworthy MR, Willcocks LC, Smith KGC. FcyRIIB, Fc $\gamma$ RIIIB, and systemic lupus erythematosus. Ann N Y Acad Sci. (2010) 1183:69-88. doi: 10.1111/j.1749-6632.2009.05132.x

35. Franke L, Bannoudi H, Jansen DTSL, Kok K, Trynka G, Diogo D, et al. Association analysis of copy numbers of FC-gamma receptor genes for rheumatoid arthritis and other immune-mediated phenotypes. Eur J Hum Genet. (2016) 24:263-70. doi: 10.1038/ejhg.2015.95

36. Martorana D, Bonatti F, Alberici F, Gioffredi A, Reina M, Urban ML, et al. Fc $\gamma$-receptor 3B (FCGR3B) copy number variations in patients with eosinophilic granulomatosis with polyangiitis. J Allergy Clin Immunol. (2016) 137:1597-9.e8. doi: 10.1016/j.jaci.2015.09.053

37. Lassaunière R, Shalekoff $S$, Tiemessen CT. A novel FCGR3A intragenic haplotype is associated with increased FcrRIIIa/CD16a cell surface density and population differences. Hum Immunol. (2013) 74:627-34. doi: 10.1016/j.humimm.2013.01.020

38. Huizinga TW, Kerst M, Nuyens JH, Vlug A, Borne AE, Roos D, et al. Binding characteristics of dimeric IgG subclass complexes to human neutrophils. $J$ Immunol. (1989) 142:2359-64.

39. Huizinga TW, Roos D, von dem Borne, AE. Neutrophil Fc-gamma receptors: a two-way bridge in the immune system. Blood (1990) 75:1211-4.

40. Clarkson SB, Ory PA. CD16. Developmentally regulated IgG Fc receptors on cultured human monocytes. J Exp Med. (1988) 167:408-20. doi: $10.1084 /$ jem.167.2.408

41. Herter S, Birk MC, Klein C, Gerdes C, Umana P, Bacac M. Glycoengineering of therapeutic antibodies enhances monocyte/macrophage-mediated phagocytosis and cytotoxicity. J Immunol. (2014) 192:2252-60. doi: 10.4049/jimmunol.1301249

42. Perussia B, Acuto O, Terhorst C, Faust J, Lazarus R, Fanning V, et al. Human natural killer cells analyzed by B73.1, a monoclonal antibody blocking Fc receptor functions. II. Studies of B73.1 antibody-antigen interaction on the lymphocyte membrane. J Immunol. (1983) 130:2142-8.

43. de La Salle C, Esposito-Farese M-E, Bieber T, Moncuit J, Morales M, Wollenberg A, et al. Release of soluble Fc $\gamma$ RII/CD32 molecules by human langerhans cells: a subtle balance between shedding and secretion? J Invest Dermatol. (1992) 99:S15-7. doi: 10.1111/1523-1747.ep12668250

44. Sármay G, Rozsnyay Z, Gergely J. Fc $\gamma$ RII expression and release on resting and activated human B lymphocytes. Molecul Immunol. (1990) 27:1195-200. doi: 10.1016/0161-5890(90)90022-R

45. Huizinga TWJ, van der Schoot CE, Jost C, Klaassen R, Kleijer M, von dem Borne AEGK, et al. The Pi-linked receptor FcRIII is released on stimulation of neutrophils. Nature (1988) 333:667-9. doi: 10.1038/333667a0

46. Jing $\mathrm{Y}, \mathrm{Ni} \mathrm{Z}, \mathrm{Wu}$ J, Higgins L, Markowski TW, Kaufman DS, et al. Identification of an ADAM17 cleavage region in human CD16 (Fc $\gamma$ RIII) and the engineering of a non-cleavable version of the receptor in NK cells. PLoS ONE (2015) 10:e0121788. doi: 10.1371/journal.pone.0121788

47. Middelhoven P, Ager A, Roos D, Verhoeven A. Involvement of a metalloprotease in the shedding of human neutrophil Fc $\gamma$ RIIIB. FEBS Lett. (1997) 414:14-8. doi: 10.1016/S0014-5793(97)00959-9

48. Galon J, Moldovan I, Galinha A, Provost-Marloie MA, Kaudewitz H, RomanRoman S, et al. Identification of the cleavage site involved in production of plasma soluble Fc gamma receptor type III (CD16). Eur J Immunol. (1998) 28:2101-7. doi: 10.1002/(SICI)1521-4141(199807)28:07\&1t;2101::AIDIMMU2101\&gt;3.0.CO;2-W

49. Huizinga TW, de Haas M, Kleijer M, Nuijens JH, Roos D, Borne AE. Soluble Fc gamma receptor III in human plasma originates from release by neutrophils. J Clin Invest. (1990) 86:416-23. doi: 10.1172/JCI114727

50. Teillaud JL, Bouchard C, Astier A, Teillaud C, Tartour E, Michon J, et al. Natural and recombinant soluble low-affinity Fc $\gamma \mathrm{R}$ : detection, purification, and functional activities. ImmunoMethods (1994) 4:48-64. doi: 10.1006/immu.1994.1007

51. Galon J, Gauchat JF, Mazières N, Spagnoli R, Storkus W, Lötze M, et al. Soluble Fcgamma receptor type III (FcgammaRIII, CD16) triggers cell activation through interaction with complement receptors. J Immunol. (1996) 157:1184-92.

52. Srpan K, Ambrose A, Karampatzakis A, Saeed M, Cartwright ANR, Guldevall K, et al. Shedding of CD16 disassembles the NK cell immune synapse and boosts serial engagement of target cells. J Cell Biol. (2018) 217:3267-83. doi: $10.1083 /$ jcb.201712085 
53. Wang W, Erbe AK, Hank JA, Morris ZS, Sondel PM. NK cell-mediated antibody-dependent cellular cytotoxicity in cancer immunotherapy. Front Immunol. (2015) 6:368. doi: 10.3389/fimmu.2015.00368

54. Goodridge HS, Underhill DM, Touret N. Mechanisms of Fc receptor and dectin-1 activation for phagocytosis. Traffic (2012) 13:1062-71. doi: 10.1111/j.1600-0854.2012.01382.x

55. Bakalar MH, Joffe AM, Schmid EM, Son S, Podolski M, Fletcher DA. Size-dependent segregation controls macrophage phagocytosis of antibodyopsonized targets. Cell (2018) 174:131-42.e13. doi: 10.1016/j.cell.2018.05.059

56. Chang VT, Fernandes RA, Ganzinger KA, Lee SF, Siebold C, et al. Initiation of T cell signaling by CD45 segregation at "close contacts." Nat Immunol. (2016) 17:574-82. doi: 10.1038/ni.3392

57. Lopes FB, Balint S, Valvo S, Felce JH, Hessel EM, Dustin ML, et al. Membrane nanoclusters of FcgammaRI segregate from inhibitory SIRPalpha upon activation of human macrophages. J Cell Biol. (2017) 216:1123-41. doi: $10.1083 /$ jcb.201608094

58. Freeman SA, Vega A, Riedl M, Collins RF, Ostrowski PP, Woods EC, et al. Transmembrane pickets connect cyto- and pericellular skeletons forming barriers to receptor engagement. Cell (2018) 172:305-17.e10. doi: 10.1016/j.cell.2017.12.023

59. Flannagan RS, Harrison RE, Yip CM, Jaqaman K, Grinstein S. Dynamic macrophage "probing" is required for the efficient capture of phagocytic targets. J Cell Biol. (2010) 191:1205-18. doi: 10.1083/jcb.201007056

60. Mao YS, Yamaga M, Zhu X, Wei Y, Sun H-Q, Wang J, et al. Essential and unique roles of PIP5K- $\gamma$ and $-\alpha$ in Fc $\gamma$ receptor-mediated phagocytosis. $J$ Cell Biol. (2009) 184:281-96. doi: 10.1083/jcb.200806121

61. Lin J, Kurilova S, Scott BL, Bosworth E, Iverson BE, Bailey EM, et al. TIRF imaging of $\mathrm{Fc}$ gamma receptor microclusters dynamics and signaling on macrophages during frustrated phagocytosis. In BMC Immunol. (2016) 17:5. doi: 10.1186/s12865-016-0143-2

62. Jaumouillé V, Farkash Y, Jaqaman K, Das R, Lowell CA, Grinstein S. Actin cytoskeleton reorganization by Syk regulates $\mathrm{Fc} \gamma$ receptor responsiveness by increasing its lateral mobility and clustering. Dev Cell (2014) 29:534-46. doi: 10.1016/j.devcel.2014.04.031

63. Steblyanko M, Anikeeva N, Campbell KS, Keen JH, Sykulev Y. Integrins influence the size and dynamics of signaling microclusters in a Pyk2-dependent manner. J Biol Chem. (2015) 290:11833-42. doi: 10.1074/jbc.M114.614719

64. Hsu HT, Mace EM, Carisey AF, Viswanath DI, Christakou AE, Wiklund M., et al. NK cells converge lytic granules to promote cytotoxicity and prevent bystander killing. J Cell Biol. (2016) 215:875-89. doi: 10.1083/jcb.201604136

65. Yeap WH, Wong KL, Shimasaki N, Teo ECY, Quek JKS, Yong HX, et al. CD16 is indispensable for antibody-dependent cellular cytotoxicity by human monocytes. Sci Rep. (2016) 6:srep34310. doi: 10.1038/srep34310

66. Zhang Y, Hoppe AD, Swanson JA. Coordination of Fc receptor signaling regulates cellular commitment to phagocytosis. Proc Natl Acad Sci USA. (2010) 107:19332-7. doi: 10.1073/pnas.1008248107

67. Magenau A, Benzing C, Proschogo N, Don AS, Hejazi L, Karunakaran $\mathrm{D}$, et al. Phagocytosis of IgG-coated polystyrene beads by macrophages induces and requires high membrane order. Traffic (2011) 12:1730-43. doi: 10.1111/j.1600-0854.2011.01272.x

68. Kono H, Kyogoku C, Suzuki T, Tsuchiya N, Honda H, Yamamoto K, et al. FcgammaRIIB Ile232Thr transmembrane polymorphism associated with human systemic lupus erythematosus decreases affinity to lipid rafts and attenuates inhibitory effects on B cell receptor signaling. Hum Mol Genet. (2005) 14:2881-92. doi: 10.1093/hmg/ddi320

69. Scheiffele $\mathrm{P}$, Roth MG, Simons K. Interaction of influenza virus haemagglutinin with sphingolipid-cholesterol membrane domains via its transmembrane domain. EMBO J. (1997) 16:5501-8. doi: $10.1093 / \mathrm{emboj} / 16.18 .5501$

70. García-García E, Nieto-Castañeda G, Ruiz-Saldaña M, Mora N, Rosales C. FcgammaRIIA and FcgammaRIIIB mediate nuclear factor activation through separate signaling pathways in human neutrophils. J Immunol. (2009) 182:4547-56. doi: 10.4049/jimmunol.0801468

71. Coxon A, Cullere X, Knight S, Sethi S, Wakelin MW, Stavrakis $\mathrm{G}$, et al. FcyRIII mediates neutrophil recruitment to immune complexes: a mechanism for neutrophil accumulation in immune-mediated inflammation. Immunity (2001) 14:693-704. doi: 10.1016/S1074-7613(01)00150-9

72. Zhou MJ, Brown EJ. CR3 (Mac-1, alpha M beta 2, CD11b/CD18) and Fc gamma RIII cooperate in generation of a neutrophil respiratory burst: requirement for Fc gamma RIII and tyrosine phosphorylation. J Cell Biol. (1994) 125:1407-16. doi: 10.1083/jcb.125.6.1407

73. Zhou M, Lublin DM, Link DC, Brown EJ. Distinct tyrosine kinase activation and triton X-100 insolubility upon Fc $\gamma$ RII or Fc $\gamma$ RIIIB ligation in human polymorphonuclear leukocytes. Implications for immune complex activation of the respiratory burst. J Biol Chem. (1995) 270:13553-60. doi: $10.1074 /$ jbc.270.22.13553

74. Anderson CL, Shen L, Eicher DM, Wewers MD, Gill JK. Phagocytosis mediated by three distinct Fc gamma receptor classes on human leukocytes. J Exp Med. (1990) 171:1333-45. doi: 10.1084/jem.171.4.1333

75. David A, Fridlich R, Aviram I. The presence of membrane Proteinase 3 in neutrophil lipid rafts and its colocalization with FcgammaRIIIb and cytochrome b558. Exp Cell Res. (2005) 308:156-65. doi: 10.1016/j.yexcr.2005.03.034

76. Fernandes MJG, Rollet-Labelle E, Paré, G, Marois S, Tremblay ML, Teillaud JL, et al. CD16b associates with high-density, detergentresistant membranes in human neutrophils. Biochem J. (2006) 393:351-9. doi: 10.1042/BJ20050129

77. Green JM, Schreiber AD, Brown EJ. Role for a glycan phosphoinositol anchor in Fc $\gamma$ receptor synergy. J Cell Biol. (1997) 139:1209-17. doi: $10.1083 /$ jcb.139.5.1209

78. Marois L, Paré G, Vaillancourt M, Rollet-Labelle E, Naccache PH. Fc gammaRIIIb triggers raft-dependent calcium influx in IgG-mediated responses in human neutrophils. J Biol Chem. (2011) 286:3509-19. doi: 10.1074/jbc.M110.169516

79. Munro S. Lipid rafts: elusive or illusive? Cell (2003) 115:377-88. doi: 10.1016/S0092-8674(03)00882-1

80. Paulick MG, Bertozzi CR. The glycosylphosphatidylinositol anchor: a complex membrane-anchoring structure for proteins. Biochemistry (2008) 47:6991-7000. doi: 10.1021/bi8006324

81. Yang H, Jiang H, Song Y, Chen DJ, Shen XJ, Chen JH. Neutrophil CD16b crosslinking induces lipid raft-mediated activation of SHP-2 and affects cytokine expression and retarded neutrophil apoptosis. Exp Cell Res. (2018) 362:121-31. doi: 10.1016/j.yexcr.2017.11.009

82. Zhou M, Todd RF, van de Winkel JG, Petty HR. Cocapping of the leukoadhesin molecules complement receptor type 3 and lymphocyte function-associated antigen-1 with Fc gamma receptor III on human neutrophils. Possible role of lectin-like interactions. J Immunol. (1993) 150:3030-41.

83. Golay J, Roit FD, Bologna L, Ferrara C, Leusen JH, Rambaldi A, et al. Glycoengineered CD20 antibody obinutuzumab activates neutrophils and mediates phagocytosis through CD16B more efficiently than rituximab. Blood (2013) 122:3482-91. doi: 10.1182/blood-2013-05-504043

84. Chesla SE, Li P, Nagarajan S, Selvaraj P, Zhu C. The membrane anchor influences ligand binding two-dimensional kinetic rates and threedimensional affinity of Fc $\gamma$ RIII (CD16). J Biol Chem. (2000) 275:10235-46. doi: $10.1074 /$ jbc.275.14.10235

85. Jiang N, Chen W, Jothikumar P, Patel JM, Shashidharamurthy R, Selvaraj P, et al. Effects of anchor structure and glycosylation of Fc $\gamma$ receptor III on ligand binding affinity. Mol Biol Cell (2016) 27:3449-58. doi: 10.1091/mbc.e16-06-0470

86. Moremen KW, Tiemeyer M, Nairn AV. Vertebrate protein glycosylation: diversity, synthesis and function. Nat Rev Molecul Cell Biol. (2012) 13:44862. doi: $10.1038 / \mathrm{nrm} 3383$

87. Hirschberg CB, Robbins PW, Abeijon C. Transporters of nucleotide sugars, ATP, and nucleotide sulfate in the endoplasmic reticulum and Golgi apparatus. Annu Rev Biochem. (1998) 67:49-69. doi: 10.1146/annurev.biochem.67.1.49

88. Wheeler SF, Rudd PM, Davis SJ, Dwek RA, Harvey DJ. Comparison of the $\mathrm{N}$-linked glycans from soluble and GPI-anchored CD59 expressed in CHO cells. Glycobiology (2002) 12:261-71. doi: 10.1093/glycob/12.4.261

89. Thaysen-Andersen M, Packer NH. Site-specific glycoproteomics confirms that protein structure dictates formation of $\mathrm{N}$-glycan type, core fucosylation 
and branching. Glycobiology (2012) 22:1440-52. doi: 10.1093/glycob/c ws110

90. Varki A. Biological roles of glycans. Glycobiology (2017) 27:3-49. doi: 10.1093/glycob/cww086

91. Chui D, Sellakumar G, Green R, Sutton-Smith M, McQuistan T, Marek K, et al. Genetic remodeling of protein glycosylation in vivo induces autoimmune disease. Proc Natl Acad Sci USA. (2001) 98:1142-7. doi: 10.1073/pnas.98.3.1142

92. Lee SJ, Evers S, Roeder D, Parlow AF, Risteli J, Risteli L, et al. Mannose receptor-mediated regulation of serum glycoprotein homeostasis. Science (2002) 295:1898-901. doi: 10.1126/science.1069540

93. Subedi GP, Barb AW. The structural role of antibody Nglycosylation in receptor interactions. Structure (2015) 23:1573-83. doi: 10.1016/j.str.2015.06.015

94. Chen G, Wang Y, Qiu L, Qin X, Liu H, Wang X, et al. Human IgG Fc-glycosylation profiling reveals associations with age, sex, female sex hormones and thyroid cancer. J Proteom. (2012) 75:2824-34. doi: 10.1016/j.jprot.2012.02.001

95. Dekkers G, Rispens T, Vidarsson G. Novel concepts of altered immunoglobulin G galactosylation in autoimmune diseases. Front Immunol. (2018) 9:553. doi: 10.3389/fimmu.2018.00553

96. Gardinassi LG, Dotz V, Hipgrave Ederveen A, de Almeida RP, Nery Costa $\mathrm{CH}$, Costa DL, et al. Clinical severity of visceral leishmaniasis is associated with changes in immunoglobulin $\mathrm{g}$ fc $\mathrm{N}$-glycosylation. MBio (2014) 5:e01844. doi: 10.1128/mBio.01844-14

97. Yu X, Wang Y, Kristic J, Dong J, Chu X, Ge S, et al. Profiling IgG Nglycans as potential biomarker of chronological and biological ages: a community-based study in a Han Chinese population. Medicine (2016) 95:e4112. doi: 10.1097/MD.0000000000004112

98. Subedi GP, Barb AW. The immunoglobulin G1 N-glycan composition affects binding to each low affinity Fc $\gamma$ receptor. MAbs (2016) 8:1512-24. doi: 10.1080/19420862.2016.1218586

99. Bruggeman CW, Dekkers G, Visser R, Goes NWM, van den Berg TK, Rispens $\mathrm{T}$, et al. IgG glyco-engineering to improve IVIg potency. Front Immunol. (2018) 9:2442. doi: 10.3389/fimmu.2018.02442

100. Li T, DiLillo DJ, Bournazos S, Giddens JP, Ravetch JV, Wang L-X. Modulating IgG effector function by Fc glycan engineering. Proc Natl Acad Sci USA. (2017) 114:3485-90. doi: 10.1073/pnas.1702173114

101. Fleit HB, Kuhnle M. Biochemical characterization of an Fc gamma receptor purified from human neutrophils. J Immunol. (1988) 140:3120-5.

102. Lanier LL, Ruitenberg JJ, Phillips JH. Functional and biochemical analysis of CD16 antigen on natural killer cells and granulocytes. J Immunol. (1988) 141:3478-85.

103. Edberg JC, Barinsky M, Redecha PB, Salmon JE, Kimberly RP. Fc gamma RIII expressed on cultured monocytes is a N-glycosylated transmembrane protein distinct from Fc gamma RIII expressed on natural killer cells. J Immunol. (1990) 144:4729-34.

104. Edberg JC, Kimberly RP. Cell type-specific glycoforms of Fc gamma RIIIa (CD16): differential ligand binding. J Immunol. (1997) 159:3849-57.

105. Galon J, Robertson MW, Galinha A, Maziéres N, Spagnoli R, Fridman W-H, et al. Affinity of the interaction between Fcgamma receptor type III (Fc $\gamma$ RIII) and monomeric human IgG subclasses. Role of Fc $\gamma$ RIII glycosylation. Eur J Immunol. (1997) 27:1928-32. doi: 10.1002/eji.1830270816

106. Hayes JM, Frostell A, Cosgrave EF, Struwe WB, Potter O, Davey GP, et al. Fc gamma receptor glycosylation modulates the binding of IgG glycoforms: a requirement for stable antibody interactions. J Proteome Res. (2014) 13:547185. doi: $10.1021 / \mathrm{pr} 500414 \mathrm{q}$

107. Jung ST, Kang TH, Georgiou G. Efficient expression and purification of human aglycosylated Fcy receptors in Escherichia coli. Biotechnol Bioeng. (2010) 107:21-30. doi: 10.1002/bit.22785

108. Hayes JM, Frostell A, Karlsson R, Müller S, Martín SM, Pauers M, et al. Identification of $\mathrm{Fc}$ gamma receptor glycoforms that produce differential binding kinetics for rituximab. Mol Cell Proteom. (2017) 16:1770-88. doi: 10.1074/mcp.M117.066944

109. Patel KR, Roberts JT, Subedi GP, and Barb AW. Restricted processing of $\mathrm{CD} 16 \mathrm{a} / \mathrm{Fc} \gamma$ receptor IIIa N-glycans from primary human NK cells impacts structure and function. J Biol Chem. (2018) 293:3477-89. doi: $10.1074 /$ jbc.RA117.001207
110. Subedi GP, Barb AW. CD16a with oligomannose-type N-glycans is the only "low affinity" Fc $\gamma$ receptor that binds the IgG crystallizable fragment with high affinity in vitro. J Biol Chem. (2018) 293:16842-50. doi: $10.1074 / j b c . R A 118.004998$

111. Yagi H, Takakura D, Roumenina LT, Fridman WH, Sautes-Fridman C, Kawasaki N, et al. Site-specific N-glycosylation analysis of soluble Fcgamma receptor IIIb in human serum. Sci Rep. (2018) 8:2719. doi: 10.1038/s41598-018-21145-y

112. Ruhaak LR, Xu G, Li Q, Goonatilleke E, Lebrilla CB. Mass spectrometry approaches to glycomic and glycoproteomic analyses. Chem Rev. (2018) 118:7886-930. doi: 10.1021/acs.chemrev.7b00732

113. Qian R, Chen C, Colley KJ. Location and mechanism of $\alpha 2,6$ Sialyltransferase dimer formation role of cysteine residues in enzyme dimerization, localization, activity, and processing. J Biol Chem. (2001) 276:28641-9. doi: 10.1074/jbc.M103664200

114. Cosgrave EF, Struwe WB, Hayes JM, Harvey DJ, Wormald MR, Rudd PM. Nlinked glycan structures of the human Fcgamma receptors produced in NS0 cells. J Proteome Res. (2013) 12:3721-37. doi: 10.1021/pr400344h

115. Falconer DJ, Subedi GP, Marcella AM, Barb AW. Antibody Fucosylation lowers the Fc $\gamma$ RIIIa/CD16a affinity by limiting the conformations sampled by the N162-Glycan. ACS Chem Biol. (2018) 13:2179-89. doi: $10.1021 /$ acschembio. 8 b00342

116. Ferrara C, Stuart F, Sondermann P, Brunker P, Umana P. The carbohydrate at FcgammaRIIIa Asn-162. An element required for high affinity binding to non-fucosylated IgG glycoforms. J Biol Chem. (2006) 281:5032-6. doi: 10.1074/jbc.M510171200

117. Shibata-Koyama M, Iida S, Okazaki A, Mori K, Kitajima-Miyama K, Saitou S, et al. The N-linked oligosaccharide at Fc $\gamma$ RIIIa Asn-45: an inhibitory element for high Fc $\gamma$ RIIIa binding affinity to IgG glycoforms lacking core fucosylation. Glycobiology (2009) 19:126-34. doi: 10.1093/glycob/cwn110

118. Subedi GP, Falconer DJ, Barb AW. Carbohydrate-polypeptide contacts in the antibody receptor CD16A identified through solution NMR spectroscopy. Biochemistry (2017) 56:3174-7. doi: 10.1021/acs.biochem.7b00392

119. Zeck A, Pohlentz G, Schlothauer T, Peter-Katalinić J, Regula JT. Cell typespecific and site directed N-glycosylation pattern of Fc $\gamma$ RIIIa. J Proteome Res. (2011) 10:3031-9. doi: 10.1021/pr1012653

120. Ory PA, Goldstein IM, Kwoh EE, Clarkson SB. Characterization of polymorphic forms of $\mathrm{Fc}$ receptor III on human neutrophils. J Clin Invest. (1989) 83:1676-81. doi: 10.1172/JCI114067

121. Salmon JE, Edberg JC, Brogle NL, Kimberly RP. Allelic polymorphisms of human Fc gamma receptor IIA and Fc gamma receptor IIIB. Independent mechanisms for differences in human phagocyte function. J Clin Invest. (1992) 89:1274-81. doi: 10.1172/JCI115712

122. Takahashi N, Cohen-Solal J, Galinha A, Fridman WH, Sautes-Fridman C, Kato K. N-glycosylation profile of recombinant human soluble Fcgamma receptor III. Glycobiology (2002) 12:507-15. doi: 10.1093/glycob/ cwf063

123. Washburn N, Meccariello R, Duffner J, Getchell K, Holte K, Prod'homme T, et al. Characterization of endogenous human Fc $\gamma$ RIII by mass spectrometry reveals site, allele and sequence specific glycosylation. Molecul Cell Proteom. (2018) 17:mcp.RA118.001142. doi: 10.1074/mcp.RA118.001142

124. Roberts JT, Barb AW. A single amino acid distorts the Fc $\gamma$ receptor IIIb / CD16b structure upon binding immunoglobulin G1 and reduces affinity relative to CD16a. J Biol Chem. (2018) 293:19899-908 doi: 10.1074/jbc.RA118.005273

125. Parren PW, Warmerdam PA, Boeije LC, Arts J, Westerdaal NA, Vlug A, et al. On the interaction of IgG subclasses with the low affinity Fc gamma RIIa (CD32) on human monocytes, neutrophils, and platelets. Analysis of a functional polymorphism to human IgG2. J Clin Invest. (1992) 90:1537-46. doi: $10.1172 / J C I 116022$

126. Harrison PT, Allen JM. High affinity IgG binding by FcgammaRI (CD64) is modulated by two distinct IgSF domains and the transmembrane domain of the receptor. Protein Eng. (1998) 11:225-32. doi: 10.1093/protein/11. 3.225

127. Shields RL, Lai J, Keck R, O'Connell LY, Hong K, Meng YG, et al. Lack of fucose on human IgG1 N-linked oligosaccharide improves binding to human Fcgamma RIII and antibody-dependent cellular toxicity. J Biol Chem. (2002) 277:26733-40. doi: 10.1074/jbc.M202069200 
128. Huang Z-Y, Barreda DR, Worth RG, Indik ZK, Kim M-K, Chien P, et al. Differential kinase requirements in human and mouse Fc-gamma receptor phagocytosis and endocytosis. J Leukoc Biol. (2006) 80:1553-62. doi: 10.1189/jlb.0106019

129. Chen K, Nishi H, Travers R, Tsuboi N, Martinod K, Wagner DD, et al. Endocytosis of soluble immune complexes leads to their clearance by Fc $\gamma$ RIIIB but induces neutrophil extracellular traps via Fc $\gamma$ RIIA in vivo. Blood (2012) 120:4421-31. doi: 10.1182/blood-2011-12-401133

130. Voice JK, Lachmann PJ. Neutrophil Fc gamma and complement receptors involved in binding soluble IgG immune complexes and in specific granule release induced by soluble IgG immune complexes. Eur J Immunol. (1997) 27:2514-23. doi: 10.1002/eji.1830271008

131. Ostreiko KK, Tumanova IA, Sykulev YK. Production and characterization of heat-aggregated IgG complexes with pre-determined molecular masses: light-scattering study. Immunol Lett. (1987) 15:311-6. doi: 10.1016/0165-2478(87)90134-9

132. St Clair JB, Detanico T, Aviszus K, Kirchenbaum GA, Christie $\mathrm{M}$, Carpenter JF, et al. Immunogenicity of Isogenic IgG in aggregates and immune complexes. PLoS ONE (2017) 12:e0170556. doi: 10.1371/journal.pone.0170556

133. Koval M, Preiter K, Adles C, Stahl PD, Steinberg TH. Size of IgG-opsonized particles determines macrophage response during internalization. Exp Cell Res. (1998) 242:265-73. doi: 10.1006/excr.1998.4110

134. Lux A, Yu X, Scanlan CN, Nimmerjahn F. Impact of immune complex size and glycosylation on IgG binding to human FcgammaRs. J Immunol. (2013) 190:4315-23. doi: 10.4049/jimmunol.1200501

135. Robinett RA, Guan N, Lux A, Biburger M, Nimmerjahn F, Meyer AS. Dissecting FcgammaR regulation through a multivalent binding model. Cell Syst. (2018) 7:41-8.e5. doi: 10.1016/j.cels.2018.05.018

136. Stopforth RJ, Oldham RJ, Tutt AL, Duriez P, Chan HTC, Binkowski BF, et al. Detection of experimental and clinical immune complexes by measuring SHIP-1 recruitment to the inhibitory Fc $\gamma$ RIIB. J Immunol. (2018) 200:193750. doi: 10.4049/jimmunol.1700832

137. Suurmond J, Diamond B. Autoantibodies in systemic autoimmune diseases: specificity and pathogenicity. J Clin Invest. (2015) 125:2194-202. doi: 10.1172/JCI78084

138. Zuercher AW, Spirig R, Baz Morelli A, Käsermann F. IVIG in autoimmune disease - Potential next generation biologics. Autoimmun Rev. (2016) 15:781-5. doi: 10.1016/j.autrev.2016.03.018

139. Samuelsson A, Towers TL, Ravetch JV. Anti-inflammatory activity of IVIG mediated through the inhibitory Fc receptor. Science (2001) 291:484-6. doi: 10.1126/science.291.5503.484

140. Nagelkerke SQ, Dekkers G, Kustiawan I, van de Bovenkamp FS, Geissler J, Plomp R, et al. Inhibition of FcgammaR-mediated phagocytosis by IVIg is independent of IgG-Fc sialylation and FcgammaRIIb in human macrophages. Blood (2014) 124:3709-18. doi: 10.1182/blood-2014-05-576835

141. Tremblay T, Paré I, Bazin R. Immunoglobulin G dimers and immune complexes are dispensable for the therapeutic efficacy of intravenous immune globulin in murine immune thrombocytopenia. Transfusion (2013) 53:261-9. doi: 10.1111/j.1537-2995.2012.03725.x

142. Kempers AC, Nejadnik MR, Rombouts Y, Ioan-Facsinay A, van Oosterhout $\mathrm{M}$, Jiskoot $\mathrm{W}$, et al. Fc gamma receptor binding profile of anti-citrullinated protein antibodies in immune complexes suggests a role for FcgammaRI in the pathogenesis of synovial inflammation. Clin Exp Rheumatol. (2018) 36:284-93.

143. Ortiz DF, Lansing JC, Rutitzky L, Kurtagic E, Prod'homme T, Choudhury A, et al. Elucidating the interplay between IgG-Fc valency and $\mathrm{Fc} \gamma \mathrm{R}$ activation for the design of immune complex inhibitors. Sci Transl Med. (2016) 8:365ra158. doi: 10.1126/scitranslmed.aaf9418

144. Qureshi OS, Rowley TF, Junker F, Peters SJ, Crilly S, Compson J, et al. Multivalent Fc $\gamma$-receptor engagement by a hexameric Fc-fusion protein triggers Fc $\gamma$-receptor internalisation and modulation of Fc $\gamma$-receptor functions. Sci Rep. (2017) 7:17049. doi: 10.1038/s41598-017-17255-8

145. Kasturirangan S, Rainey GJ, Xu L, Wang X, Portnoff A, Chen T, et al. Targeted $\mathrm{Fc} \gamma$ receptor $(\mathrm{Fc} \gamma \mathrm{R})$-mediated clearance by a biparatopic bispecific antibody. J Biol Chem. (2017) 292:4361-70. doi: 10.1074/jbc.M116.770628
146. Freeman G, Perera RAPM, Ngan E, Fang VJ, Cauchemez S, Ip DKM, et al. Quantifying homologous and heterologous antibody titer rises after influenza virus infection. Epidemiol Infect. (2016) 144:2306-16. doi: 10.1017/S0950268816000583

147. Bachmann MF, Kalinke U, Althage A, Freer G, Burkhart C, Roost H-P, et al. The role of antibody concentration and avidity in antiviral protection. Science (1997) 276:2024-7. doi: 10.1126/science.276.5321.2024

148. Gallo P, Goncalves R, Mosser DM. The influence of IgG density and macrophage Fc (gamma) receptor cross-linking on phagocytosis and IL-10 production. Immunol Lett. (2010) 133:70-7. doi: 10.1016/j.imlet.2010.07.004

149. Taborda CP, Rivera J, Zaragoza O, Casadevall A. More is not necessarily better: prozone-like effects in passive immunization with IgG. J Immunol. (2003) 170:3621-30. doi: 10.4049/jimmunol.170.7.3621

150. Chan KR, Zhang SL-X, Tan HC, Chan YK, Chow A, Lim APC, et al. Ligation of Fc gamma receptor IIB inhibits antibody-dependent enhancement of dengue virus infection. Proc Natl Acad Sci USA. (2011) 108:12479-84. doi: $10.1073 /$ pnas. 1106568108

151. Corey L, Gilbert PB, Tomaras GD, Haynes BF, Pantaleo G, Fauci AS. Immune correlates of vaccine protection against HIV-1 acquisition. Sci Transl Med. (2015) 7:310rv7. doi: 10.1126/scitranslmed.aac7732

152. Ferrante A, Beard LJ, Feldman RG. IgG subclass distribution of antibodies to bacterial and viral antigens. Pediatr Infec Dis J. (1990) 9:516. doi: 10.1097/00006454-199008001-00004

153. Yamada DH, Elsaesser H, Lux A, Timmerman JM, Morrison SL, de la Torre JC, et al. Suppression of Fcgamma-receptor-mediated antibody effector function during persistent viral infection. Immunity (2015) 42:379-90. doi: 10.1016/j.immuni.2015.01.005

154. Dowd KA, Jost CA, Durbin AP, Whitehead SS, Pierson TC. A dynamic landscape for antibody binding modulates antibody-mediated neutralization of west nile virus. PLoS Pathog. (2011) 7:e1002111. doi: 10.1371/journal.ppat.1002111

155. Mazor Y, Yang C, Borrok MJ, Ayriss J, Aherne K, Wu H, et al. Enhancement of immune effector functions by modulating IgG's intrinsic affinity for target antigen. PLoS ONE (2016) 11:e0157788. doi: 10.1371/journal.pone.0157788

156. Kim MS, Lee SH, Song MY, Yoo TH, Lee BK, Kim YS. Comparative analyses of complex formation and binding sites between human tumor necrosis factor-alpha and its three antagonists elucidate their different neutralizing mechanisms. J Mol Biol. (2007) 374:1374-88. doi: 10.1016/j.jmb.2007.10.034

157. Saphire EO, Schendel SL, Fusco ML, Gangavarapu K, Gunn BM, Wec AZ, et al. Systematic analysis of monoclonal antibodies against Ebola virus GP defines features that contribute to protection. Cell (2018) 174:938-52.e13. doi: 10.1016/j.cell.2018.07.033

158. Ferrant JL, Wilson CA, Benjamin CD, Hess DM, Hsu Y-M, Karpusas M, et al. Variation in the ordered structure of complexes between CD154 and anti-CD154 monoclonal antibodies. Molecul Immunol. (2002) 39:77-84. doi: 10.1016/S0161-5890(02)00045-7

159. Booth JW, Kim M-K, Jankowski A, Schreiber AD, Grinstein S. Contrasting requirements for ubiquitylation during $\mathrm{Fc}$ receptor-mediated endocytosis and phagocytosis. EMBO J. (2002) 21:251-8. doi: 10.1093/emboj/21.3.251

160. Cherry RJ. Rotational and lateral diffusion of membrane proteins. Biochim Biophys Acta (1979) 559:289-327. doi: 10.1016/0304-4157(79)90009-1

161. Beningo KA, Wang YL. Fc-receptor-mediated phagocytosis is regulated by mechanical properties of the target. J Cell Sci. (2002) 115:849-56.

162. Ben M'Barek K, Molino D, Quignard S, Plamont MA, Chen Y, Chavrier $\mathrm{P}$, et al. Phagocytosis of immunoglobulin-coated emulsion droplets. Biomaterials (2015) 51:270-7. doi: 10.1016/j.biomaterials.2015.02.030

163. Shashidharamurthy R, Zhang F, Amano A, Kamat A, Panchanathan R, Ezekwudo D, et al. Dynamics of the interaction of human IgG subtype immune-complexes with cells expressing $\mathrm{R}$ and $\mathrm{H}$ allelic forms of a low affinity Fc gamma receptor CD32A. J Immunol. (2009) 183:8216-24. doi: 10.4049/jimmunol.0902550

164. Bruhns P, Iannascoli B, England P, Mancardi DA, Fernandez N, Jorieux $S$, et al. Specificity and affinity of human $\mathrm{Fc} \gamma$ receptors and their polymorphic variants for human IgG subclasses. Blood (2009) 113:3716-25. doi: 10.1182/blood-2008-09-179754

165. Rowley TF, Peters SJ, Aylott M, Griffin R, Davies NL, Healy LJ, et al. Engineered hexavalent $\mathrm{Fc}$ proteins with enhanced $\mathrm{Fc}$-gamma receptor avidity 
provide insights into immune-complex interactions. Commun Biol. (2018) 1:146. doi: 10.1038/s42003-018-0149-9

166. Chow S-K, Smith C, MacCarthy T, Pohl MA, Bergman A, Casadevall A. Disease-enhancing antibodies improve the efficacy of bacterial toxin-neutralizing antibodies. Cell Host Microbe (2013) 13:417-28. doi: 10.1016/j.chom.2013.03.001

167. Bruhns P. Properties of mouse and human IgG receptors and their contribution to disease models. Blood (2012) 119:5640-9. doi: 10.1182/blood-2012-01-380121

168. Chan YN, Boesch AW, Osei-Owusu NY, Emileh A, Crowley AR, Cocklin SL, et al. IgG Binding characteristics of rhesus macaque Fc $\gamma$ R. J Immunol. (2016) 197:2936-47. doi: 10.4049/jimmunol.1502252

169. Chenoweth AM, Trist HM, Tan P-S, Wines BD, Hogarth PM. The highaffinity receptor for IgG, Fc $\gamma$ RI, of humans and non-human primates. Immunol Rev. (2015) 268:175-91. doi: 10.1111/imr.12366

170. Dekkers G, Bentlage AEH, Stegmann TC, Howie HL, Lissenberg-Thunnissen S, Zimring J, et al. Affinity of human IgG subclasses to mouse Fc gamma receptors. MAbs (2017) 9:767-73. doi: 10.1080/19420862.2017.1323159

171. Derebe MG, Nanjunda RK, Gilliland GL, Lacy ER, Chiu ML. Human IgG subclass cross-species reactivity to mouse and cynomolgus monkey $\mathrm{Fc} \gamma$ receptors. Immunol Lett. (2018) 197:1-8. doi: 10.1016/j.imlet.2018.02.006

172. Gillis C, Gouel-Chéron A, Jönsson F, Bruhns P. Contribution of human Fc $\gamma$ Rs to disease with evidence from human polymorphisms and transgenic animal studies. Front Immunol. 5:254. doi: 10.3389/fimmu.2014.00254

173. Hogarth PM, Anania JC, Wines BD. The Fc $\gamma$ R of humans and nonhuman primates and their interaction with IgG: implications for induction of inflammation, resistance to infection and the use of therapeutic monoclonal antibodies. Curr Top Microbiol Immunol. (2014) 382:321-52. doi: 10.1007/978-3-319-07911-0_15

174. Dekkers G, Bentlage AEH, Plomp R, Visser R, Koeleman CAM, Beentjes A, et al. Conserved Fc $\gamma$ R- glycan discriminates between fucosylated and afucosylated IgG in humans and mice. Mol Immunol. (2018) 94:54-60. doi: 10.1016/j.molimm.2017.12.006

175. Lux A, Seeling M, Baerenwaldt A, Lehmann B, Schwab I, Repp R., et al. A humanized mouse identifies the bone marrow as a niche with low therapeutic IgG activity. Cell Rep. (2014) 7:236-48. doi: 10.1016/j.celrep.2014.02.041

176. Smith P, DiLillo DJ, Bournazos S, Li F, Ravetch JV. Mouse model recapitulating human $\mathrm{Fc} \gamma$ receptor structural and functional diversity. Proc Natl Acad Sci USA. (2012) 109:6181-6. doi: 10.1073/pnas.1203954109

177. Trottein F, Schaffer L, Ivanov S, Paget C, Vendeville C, Groux-Degroote $S$, et al. Glycosyltransferase and sulfotransferase gene expression profiles in human monocytes, dendritic cells and macrophages. Glycoconj J. (2009) 26:1259-74. doi: 10.1007/s10719-009-9244-y

Conflict of Interest Statement: The authors declare that the research was conducted in the absence of any commercial or financial relationships that could be construed as a potential conflict of interest.

Copyright (c) 2019 Patel, Roberts and Barb. This is an open-access article distributed under the terms of the Creative Commons Attribution License (CC BY). The use, distribution or reproduction in other forums is permitted, provided the original author(s) and the copyright owner(s) are credited and that the original publication in this journal is cited, in accordance with accepted academic practice. No use, distribution or reproduction is permitted which does not comply with these terms. 